\title{
An insight into a gneiss core of the Orlica-Śnieżnik Dome, NE Bohemian Massif: new structural and U-Pb zircon data
}

\author{
Aleksandra REDLIŃSKA-MARCZYŃSKA ${ }^{1, *}$, Andrzej ŻELAŹNIEWICZ ${ }^{1,2}$ and C. Mark FANNING ${ }^{3}$ \\ 1 Adam Mickiewicz University, Institute of Geology, Maków Polnych 16, 61-606 Poznań, Poland \\ 2 Polish Academy of Science, Institute of Geological Sciences, Podwale 75, 50-449 Wrocław, Poland \\ 3 The Australian National University, Research School of Earth Sciences, Canberra 0200, Australia
}

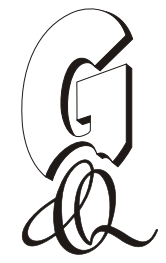

\begin{abstract}
Redlińska-Marczyńska, A., Żelaźniewicz, A., Fanning, C.M., 2016. An insight into a gneiss core of the Orlica-Śnieżnik Dome, NE Bohemian Massif: new structural and U-Pb zircon data. Geological Quarterly, 60 (3): 714-736, doi: 10.7306/gq.1287

The Orlica-Śnieżnik Dome in the Sudetes, the NE Bohemian Massif, embraces two formations of felsic gneisses of controversial origin and evolution. Our study shows that despite similar geochemical signatures, they carry systematic minor differences in mineral, isotope, zircon and geothermobarometric characteristics. Four variants of the Gierałtów gneisses include migmatites and have a longer structural history than the Śnieżnik augen orthogneisses. U-Pb SHRIMP analyses yielded $\mathrm{U}-\mathrm{Pb}$ ages of $\sim 500 \mathrm{Ma}$ for cores and $\sim 498 \mathrm{Ma}$ for wide outer parts of zircon grains in the twice-folded Gierałtów gneisses, and an age of $\sim 500 \mathrm{Ma}$ for a discordant neosome vein. Neoproterozoic metasediments were among precursors of the lithologically diversified Gierałtów Gneiss Formation. First deformation, metamorphism, and migmatisation of these rocks occurred at 515-475 Ma and overlapped with the development and emplacement of a porphyritic S-type granite precursor to the Śnieżnik Gneiss Formation. The metagranite (= Śnieżnik augen orthogneiss) embraced migmatitic xenoliths. Zircon grains from such xenoliths revealed distorted and replaced cores which yielded U-Pb ages that dispersed around 507-487 Ma, whilst wide darker poorly zoned outgrowth yielded ages from $\sim 343 \mathrm{Ma}$ to $\sim 325 \mathrm{Ma}$ (mean $\sim 340 \mathrm{Ma}$ ). These outgrowths were interpreted as a record of Carboniferous metamorphism assisted by rich Zr- and U-carrying fluids. The Variscan metamorphic overprint was heterogeneous, and variously affected rocks of the two gneiss formations.
\end{abstract}

Keywords: Cambrian, migmatites, Variscan orogeny, SHRIMP, Sudetes.

\section{INTRODUCTION}

The Orlica-Śnieżnik Dome (OSD) is a tectonostratigraphic unit in the Sudetes, SW Poland, the geological evolution of which remains debated and not fully understood (see review in Żelaźniewicz et al., 2014a). A variety of quartzo-feldspathic gneisses that appear in the core of the dome are among most controversially viewed issues. They were originally subdivided into Precambrian migmatitic gneisses of Gierałtów type and "Caledonian" metagranites of Śnieżnik type (Fischer, 1936). Such crude lithostratigraphy - Gierałtów type older than Śnieżnik type - was then contested based on various arguments (reviews in Don et al., 1990; Żelaźniewicz et al., 2002). Don (1964) proposed to reverse the order because during the field mapping he observed that the Śnieżnik type gneisses were locally cut by the mobilized Gierałtów migmatites. In contrast, detailed petrographic observations led Smulikowski (1973, 1976) to conclude that all gneisses were derived from sedimen-

\footnotetext{
* Corresponding author, e-mail: aleksandra.redlinska-marczynska@amu.edu.pl
}

Received: October 1, 2015; accepted: February 1, 2016; first published online: April 6, 2016 tary protoliths by variably intense solid-state metamorphic granitisation, the Śnieżnik type being the most advanced product of that process. Later geochemical and geochronological data furnished the base for a hypothesis that all gneisses in the dome came from a single $\sim 500 \mathrm{Ma}$ granitic protolith. The original granites were to become substantially transformed and eventually diversified during Variscan deformation and migmatisation between $360 \mathrm{Ma}$ and $340 \mathrm{Ma}$, then cooled at 340-330 Ma (Maluski et al., 1995; Turniak et al., 2000; Lange et al., 2002, 2005; Gordon et al., 2005; Bröcker et al., 2009, 2010; Štípská et al., 2012) and zonally sheared at 321 Ma (Marheine et al., 2002).

In the western limb of the OSD, however, the structural and isotopic data were found which suggested that at least some gneisses underwent high-temperature deformation prior to the Variscan events (Prikrryl et al., 1996; Redlińska-Marczyńska, 2011; Redlińska-Marczyńska and Żelaźniewicz, 2011) and were migmatised as early as $488 \mathrm{Ma}$ (Żelaźniewicz et al., 2006). Such findings hinted that the OSD likely evolved in a more complex way than assumed in a number of papers (Aleksandrowski et al., 2000; Turniak et al., 2000; Don, 2001; Lange et al., 2002, 2005; Don et al., 2003; Štípská et al., 2004). To further explore this option we have re-examined the relationships between augen gneisses and migmatitic gneisses that crop out in the Międzygórze Antiform (Fig. 1) and performed $\mathrm{U}-\mathrm{Pb}$ isotopic analyses of zircons retrieved from the samples 





with known structural position and history. In this paper, we summarize the results of structural and petrological re-examination, report new results of the U-Pb SHRIMP datings, and discuss local and regional implications of the collected data.

\section{GEOLOGICAL FRAMEWORK}

The Orlica-Śnieżnik Dome (OSD) is the easternmost unit of the Lugian domain (sensu Suess, 1912), in the NE part of the Bohemian Massif (Fig. 1). Lithostratigraphic and tectonometamorphic characteristics of the OSD are used to show affinity alternatively with the Saxothuringian or Moldanubian terranes (zones) of the European Variscides (see Franke et al., 1993; Aleksandrowski and Mazur, 2002; Żelaźniewicz et al., 2006; Jastrzębski et al., 2010; Mazur et al., 2012, 2013; Štípská et al., 2012). In the Orlica-Śnieżnik Dome, the gneissic core is mantled by a $\sim 6000 \mathrm{~m}$ thick metasedimentary succession of Ediacaran-Early Paleozoic age, referred to as the Młynowiec-Stronie Group (Gunia, 1974; Gunia and Wierzchołowski, 1979; Jastrzębski et al., 2010; Mazur et al., 2012; Żelaźniewicz et al., 2014b). The $\mathrm{F}_{(1-n)}$ or $D_{(1-n)}$ labelled successive stages of the deformational stories of the OSD rocks which have been proposed in the literature differ remarkably between various authors (reviews in Don et al., 1990; Żelaźniewicz et al., 2002, 2014a). However, there is almost a consensus that (1) the main tectonism in the OSD was controlled by the Variscan collision between the two terranes, namely Saxothuringia/Moldanubia and Brunovistulia, both ultimately of peri-Gondwana descent, and (2) the main fold structures strike generally in the $\mathrm{N}-\mathrm{S}$ direction. The oldest foliation that followed bedding planes in the metasedimentary mantle rocks was folded and transposed to the subvertical axial planar foliation due to an early E-W subhorizontal shortening and then refolded during subvertical shortening. Such tectonic template is favoured by most authors although identification and labelling of consecutive structures differ in details (Dumicz, 1979; Jastrzębski, 2005, 2009; Murtezi, 2006; Skrzypek et al., 2011, 2014; Chopin et al., 2012a, b). Similar structural succession is often assumed for the core gneisses, which seems controversial and not necessarily correct (Żelaźniewicz at al., 2014a, b). This topic will be addressed below.

\section{CHARACTERISTICS OF GNEISSES}

\section{TWO GNEISS FORMATIONS}

The original subdivision of the OSD gneisses into two types, Gierałtów and Śnieżnik, appeared too general for purposes of detailed mapping, thus required further subdivisions (e.g., Don et al., 2003). However, the descriptive criteria, such as grain-size, colour, or kind of lamination/layering, turned out sometimes to be ambiguous and even misleading (Dumicz, 1989; Don et al., 1990; Żelaźniewicz et al., 2002). Based on combined field relationships and petrographical as well as structural characteristics, Redlińska-Marczyńska and Żelaźniewicz (2011) proposed to distinguish six lithological variants easily identifiable in the field: (1) augen (ortho)gneisses, (2) migmatites, (3) layered and streaky gneisses, (4) banded gneisses, (5) porphyroblastic gneisses, and (6) mylonites to ultramylonites. Augen gneisses (1) were assigned to the Śnieżnik Gneiss Formation. Varieties (2) to (5) were assigned to the Gieraltów Gneiss Formation. Mylonitic gneisses (6) developed at the expense of rocks of either formation. Actually, we do support the long established subdivision of gneisses in the Orlica-Śnieżnik Dome into two major types, herein referred to as the Śnieżnik and Gierałtów formations (Figs. 2-4). In the Miedzygórze Antiform, the outcrop pattern and field relationships clearly depict a map view of an inlier of the Gierałtów Formation rocks within the Śnieżnik gneisses (Fig. 1). In our opinion, the antiform is a folded, large-scale enclave of the high-grade migmatitic gneisses set in the porphyritic metagranite. There is a "transitional zone" (Teisseyre, 1973; Don et al., 2003) between the two types where most variants occur side by side (Redlińska-Marczyńska and Żelaźniewicz, 2011; Żelaźniewicz et al., 2014b).

One of important differences between the two gneiss formations lies in rocks enclosed in them. HP eclogite, retroeclogite/amphibolite, and granulite bodies of various dimensions occur exclusively within the Gieraltów Gneiss Formation. In the Śnieżnik Gneiss Formation, there are xenoliths of
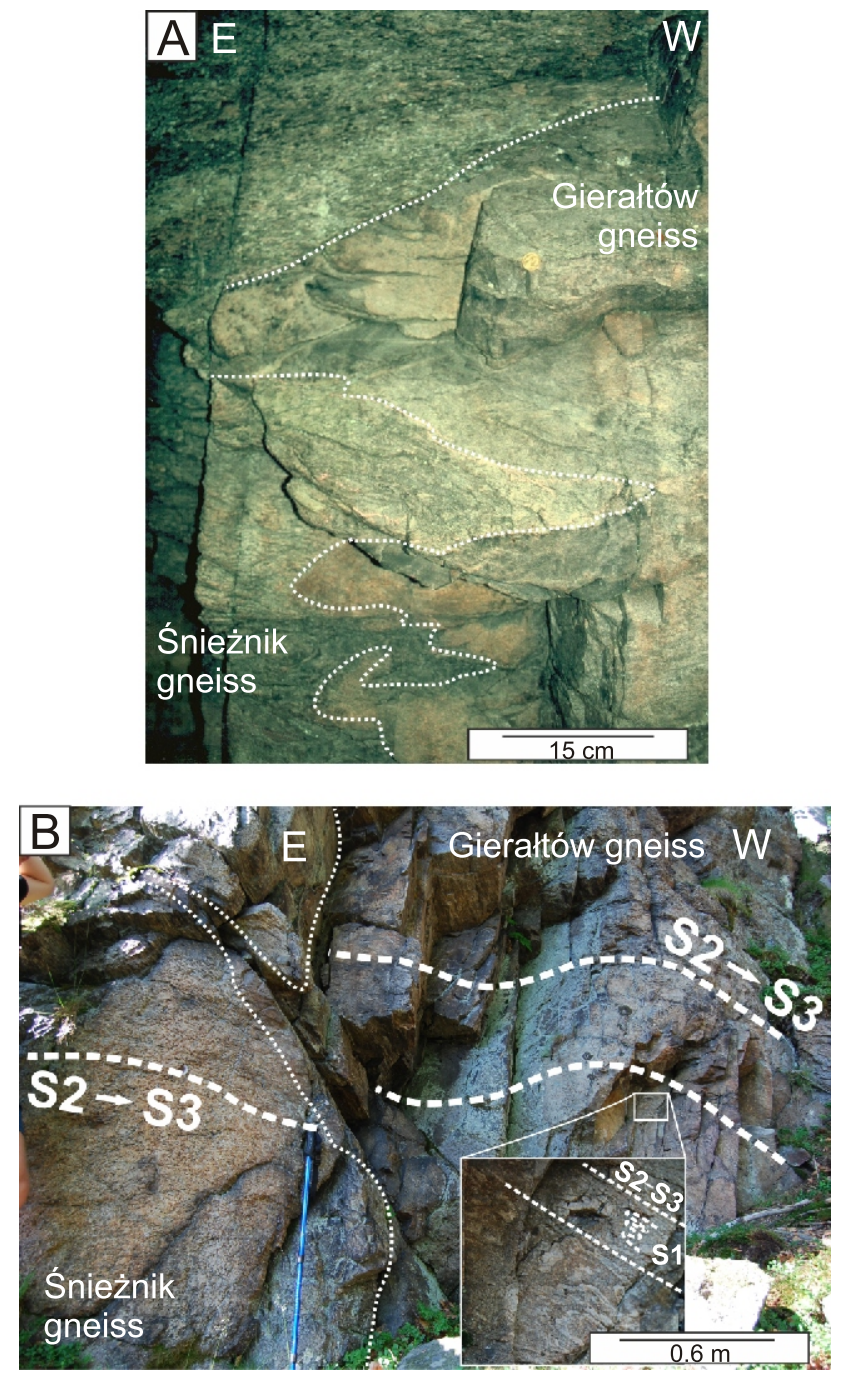

Fig. 2. Relic primary intrusive contacts between the Gierałtów gneisses and Śnieżnik gneisses (see also Fig. 4C)

A - originally steep intrusive interface between the gneisses was subjected to later deformations; $\mathbf{B}$ - both rocks were deformed in common during D3 shearing, when S2 planes were rejuvenated in the Gierałtów gneisses (S2 $\rightarrow$ S3) whereas in the Śnieżnik gneisses the first foliation set developed and became folded (see also Figs. $3 \mathrm{~F}$ and $4 \mathrm{C}$ ), thus the structural history of the latter was evidently shorter than that of the former 

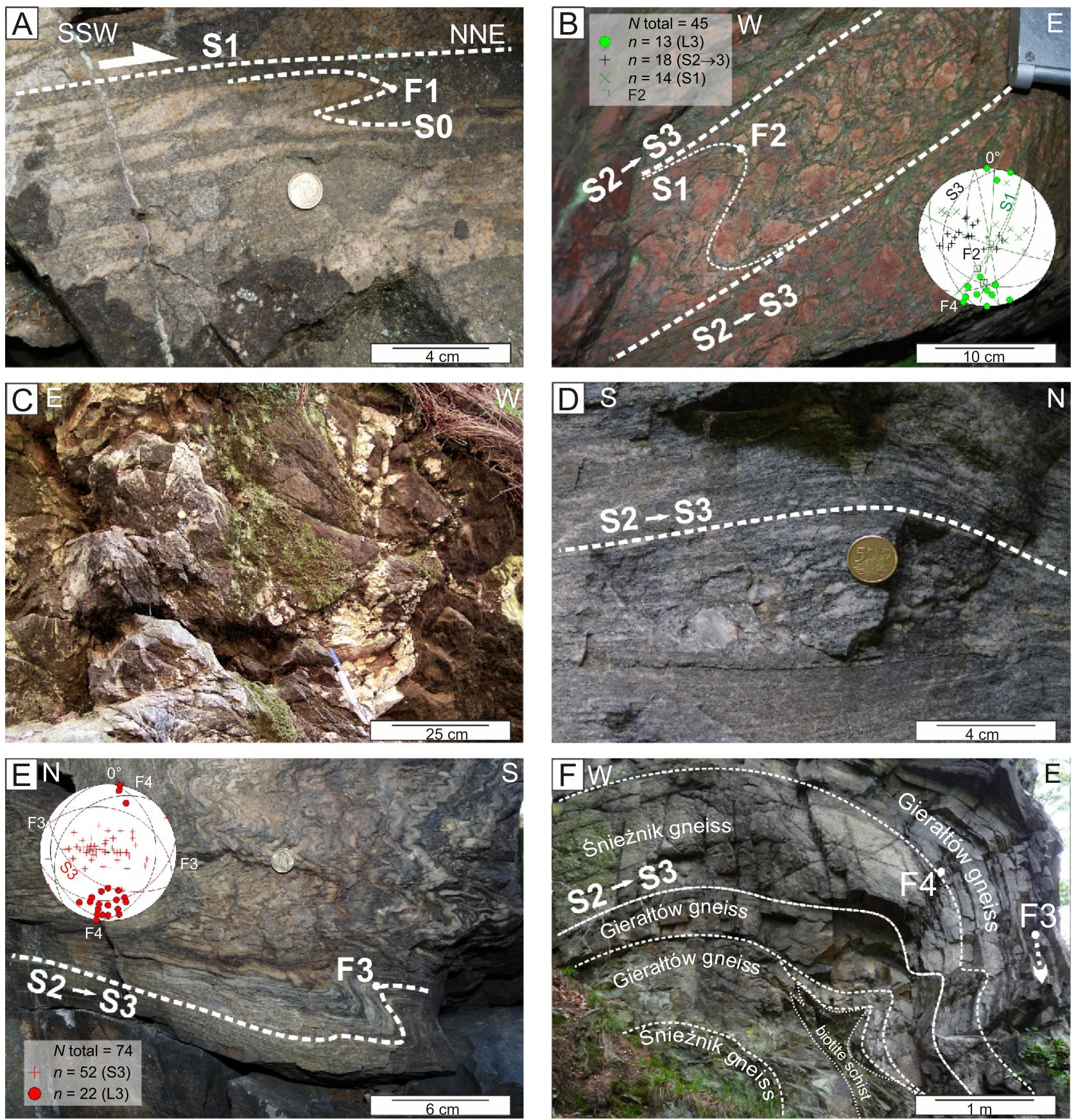

Fig. 3. Structural characteristics of gneisses in the Międzygórze Antiform

(stereographic projections on the lower hemisphere, equal angle net)

A - Gierałtów gneiss: compositional banding (S0) involved in F1 folds and subsequent shearing along S1, which brought about intrafolial folds; B - Gierałtów gneiss: porphyroblastic variant with K-feldspar and polymineral quartz-feldspar blasts nucleated intra- to post-kinematically with respect to small-scale folds F2; C - Gierałtów migmatitic gneiss: unfoliated, irregular leucocratic veins (leucosome nests) that cut discordantly the twice foliated host gneiss; D - D3 sheared migmatitic Gierałtów gneiss: note less deformed pod with relic magmatic fabric surrounded by anastomosing mylonitic foliation, top-to-the $\mathrm{N}$ vergence; $\mathrm{E}$ - Śnieżnik augen gneiss: details of $\mathrm{F} 3$ fold in S2 $\rightarrow \mathrm{S} 3$ foliation (diagram shows folds F3 and F4); F - Śnieżnik/Gierałtów gneiss transitional zone (sensu Teisseyre, 1957, 1973): alternation of banded migmatitic gneisses (Gierałtów) and augen gneisses (Śnieżnik), both strongly sheared in S2 $\rightarrow$ S3 and involved successively in F3 and F4 folds, note sheared biotite schist relict within the migmatite

fine-grained biotite gneisses, migmatitic gneisses and schists (Grześkowiak and Żelaźniewicz, 2002; Redlińska-Marczyńska and Żelaźniewicz, 2011). The xenoliths indicate that a porphyritic granite precursor to the Śnieżnik gneisses must have been genetically linked with migmatitisation and that some migmatites were older or broadly coeval with that granite. More- over, relic discordant intrusive contacts are in evidence, which clearly shows that the porphyritic granite, now the poorly foliated Snieżnik gneiss, was originally emplaced into well-foliated migmatitic gneiss of Gierałtów type (Fig. 2).

On a geochemical ground, all gneisses carry similar peraluminous, calc-alkaline granite signatures and limited vari- 



Fig. 4. Structural features of gneisses of the two formations

A - L > S augen gneiss as in sample OS47; B - Śnieżnik orthogneiss with genuine augens (K-feldspar porphyroclasts), stretching lineation $\mathrm{L} 3$ and mylonitic foliation ( $\mathrm{L}<\mathrm{S}$-tectonite), note less deformed pods of the initial coarse-grained porphyritic granite elongated in the L3 (Lelg) direction and subjected to flattening in S2 $\rightarrow$ S3 (diagram shows folding by E-vergent F4 folds); primary intrusive contact between the Gierałtów gneiss (folded and migmatised) and the Śnieżnik (meta)granite; C - folded migmatitic gneiss xenolith within the Śnieżnik augen gneisses which contain the single foliation set equivalent to $S 2 \rightarrow$ S3 planes in the Gieraltów gneisses, the pictured interface is a small-scale model of the primary contacts between the Śnieżnik granite and folded Gierałtów gneisses; D - migmatitic gneiss xenolith as in sample OS5

ations in the REE concentrations. The existing differences were found by many authors to be insufficient to distinguish between the protoliths of the Śnieżnik and Gierałtów gneisses (Maluski et al., 1995; Kröner et al., 2000; Turniak et al., 2000; Lange et al., 2005; Bröcker et al., 2009). Therefore, all the gneisses have often been interpreted as coming from one igneous suite, derived from identical source rocks. However, meticulous studies performed by Borkowska et al. (1990) and Borkowska (1994, 1996) showed that the protoliths of the two main gneiss types noticeably differed in their geochemistry with the amount of major ( $\mathrm{Si}, \mathrm{Al}, \mathrm{Mg}, \mathrm{Na})$ and trace $(\mathrm{Ba}, \mathrm{Sr}$ ) elements and $\mathrm{Rb}-\mathrm{Sr}$ systematics. For such reasons, two separate protoliths were inferred by the latter authors, or, alternatively, one protolith, albeit chemically diversified by intrusive processes. Indeed, the similarities in geochemistry strongly suggest derivation from a similar rock complex, which does not necessarily imply that the Śnieżnik and Gierałtów gneisses originated from one magma body or that their protoliths passed all through a magma stage.

\section{MINERAL, ISOTOPE, ZIRCON AND GEOTHERMOBAROMETRIC} CHARACTERISTICS

Despite geochemical similarities of the Gierałtów and Śnieżnik formations, microscopic studies reveal some system- atic variations in modal compositions between gneisses of the two formations and migmatite xenoliths found within the Śnieżnik gneisses (details in Redlińska-Marczyńska, 2011; Redlińska-Marczyńska and Żelaźniewicz, 2011). Utilizing $>13,000$ microprobe analyses, statistically significant differences have been demonstrated for these rocks and briefly compared in Table 1.

Minor differences between the two types of gneisses were observed in the isotope characteristics (Lange et al., 2005; Pin et al., 2007). Generally, values of $\varepsilon \mathrm{Nd}_{500}$ are up to 3 times more scattered in the Gierałtów $(-0.3$ to -7.1$)$ than in the Śnieżnik $(-3.5$ to -5.2$)$ gneisses, which also display a narrower range of $\mathrm{T}_{\mathrm{DM}}$ ages $(1.6-1.5 \mathrm{Ga})$. Initial ${ }^{87} \mathrm{Sr} /{ }^{86} \mathrm{Sr}$ ratios are again more scattered in the Gieraltów gneisses. Such values indicate that the Śnieżnik gneisses represent less heterogeneous rocks than the Gieraltów gneisses (Redlińska-Marczyńska and Żelaźniewicz, 2011). Indeed, modal composition of the latter rocks, xenoliths inclusive, is statistically more diversified and heterogeneous than that of the Śnieżnik metagranite (Table 1). Such trend is consistent with the evolutionary tendency of granitic melts that acquire less diversified (lithological, petrographical, isotopic and structural) features than the source rocks. Consequently, the Śnieżnik magma is assumed to be an advanced product of the processes that also produced the 
Ta ble 1

Summary of mineral and modal compositions of gneisses of the two formations $(\sim 13,000$ analytical spots in $\sim 150$ thin sections - for details see Redlińska-Marczyńska, 2011 and Redlińska-Marczyńska and Zelaźniewicz, 2011)

\begin{tabular}{|l|c|c|c|c|}
\hline \multicolumn{2}{|c|}{ Item/characteristics } & $\begin{array}{c}\text { Śnieżnik Augen } \\
\text { Gneiss Formation }\end{array}$ & $\begin{array}{c}\text { Xenoliths in the } \\
\text { Snieżnik gneisses }\end{array}$ & $\begin{array}{c}\text { Gierałtów Gneiss } \\
\text { Formation }\end{array}$ \\
\hline Alkali/K-feldspar & Mode & $26-36$ vol\% & $16-30$ vol\% & $16-34$ vol\% \\
\hline \multirow{2}{*}{$\begin{array}{l}\text { Plagioclase } \\
\text { normally zoned }\end{array}$} & Mode & $20-30$ vol\% & $22-45$ vol\% & $20-40$ vol\% \\
\cline { 2 - 5 } Biotite & An content & $6-23$ & $6-34$ & $6-38$ \\
\hline \multirow{3}{*}{ White mica } & Ti content & $<0.39$ a.p.f.u. & $<0.56$ a.p.f.u. & $<0.56$ a.p.f.u. \\
\hline \multirow{5}{*}{ Garnet } & $\mathrm{Fe}_{[\text {tot }} / \mathrm{Mg}$ & $<1.4$ & $<3.7$ & $<3.5$ \\
\cline { 2 - 5 } & $\mathrm{Si}$ & $3.0-3.37$ a.p.f.u. & $3.05-3.43$ a.p.f.u. & $3.0-3.43$ a.p.f.u. \\
\cline { 2 - 5 } & Almandine & $45-67 \%$ & $44-70 \%$ & $43-70 \%$ \\
\cline { 2 - 5 } & Grossular & $30-53 \%$ & $15-56 \%$ & $30-52 \%$ \\
\cline { 2 - 5 } & Spessartine & $0-20 \%$ & $0-20 \%$ & $0-8 \%$ \\
\cline { 2 - 5 } & Pyrope & $1-7 \%$ & $0-1.5 \%$ & $0-7 \%$ \\
\cline { 2 - 5 } & Andradite & $0-2 \%$ & $0-1.5 \%$ & $0-4 \%$ \\
\hline \multirow{2}{*}{ Titanite } & $\mathrm{X}_{\mathrm{Al}}=[$ Al/(Al+Ti)] & $<0.18$ a.p.f.u. & $<0.37$ a.p.f.u. & $<0.41$ a.p.f.u. \\
\hline
\end{tabular}

migmatitic Gierałtów gneisses or it was derived by melting from these or alike rocks. The mentioned geochemical similarities between the gneisses are not in conflict with such assumption and are in line with the preserved intrusive contacts.

Such model can also explain why garnet in both types of gneisses and in xenoliths is generally similar, though with large compositional scatter. Indeed, inherited metamorphic garnet is present in numerous garnetiferous plutons, especially peraluminous ones, which occur in metamorphic terranes (Chamberlain and Lyons, 1983; Plank, 1987; Lackey et al., 2006).The composition of garnet xenocrysts may depend solely on the bulk composition and metamorphic grade of the source rock (Spear, 1993; Owen and Marr, 1999). The grossular content is controlled by the bulk composition and increases (at the expense of $\mathrm{Mn}$ ) with the depth of crystallisation, but the increasing spessartine content of garnet stabilizes this mineral to low pressures (Miller and Stoddard, 1978, 1981). It is worth to note that high-Al titanite is also stable over a wide P-T range even under high-grade conditions (Markl and Piazolo, 2004; Lucassen et al., 2010). Therefore, such metamorphic minerals can be expected to occur in felsic magmatic rocks developed via partial melting of crustal sources. The above-briefed differences in the spessartine content in garnet, Si content in white mica, or ilmenite and titanomagnetite microgrowths observed in the studied rocks are in line with such expectations (Redlińska-Marczyńska, 2011; Redlińska-Marczyńska and Żelaźniewicz, 2011).

Turniak et al. (2000) studied typology of zircon grains in 17 gneiss samples and found that the zircons from the Śnieżnik gneisses resemble those from S-type granites, whereas the zircons from the Gieraltów gneisses point to I-type granitoids. In the former, the $\{211\}$ bipyramid dominates over the $\{101\}$, which is opposite to the Gieraltów zircons, yet in both gneisses the $\{110\}$ prism is better developed than $\{100\}$. Such observations are basically valid in our samples too, though we did not conduct a systematic typology study of a greater number of zircon populations. Nevertheless, differences in precursors of the two types of gneisses can be reasonably expected.

For gneisses of the Międzygórze Antiform, regardless of methods used, the geothermobarometric calculations range between $4-11 \mathrm{kbar} / 600-650^{\circ} \mathrm{C}$ (Klemd et al., 1995) and
4-14 kbar $/ 500-570^{\circ} \mathrm{C}$ (Grześkowiak, 2004; Redlińska-Marczyńska, 2011). Higher values of $<15 \mathrm{kbar} /<700^{\circ} \mathrm{C}$ to 19-20 kbar $/>700^{\circ} \mathrm{C}$ were recently obtained from P-T pseudosections and compositional isopleths for various minerals by Chopin et al. (2012a) who, however, did not refer to the classification of gneisses into the Śnieżnik and Gieraltów types. The highest values were determined for the Gieraltów type gneisses which were interpreted by these authors as an ultramylonite derived from the augen orthogneiss of Śnieżnik type. Although our observations also repeatedly show that the Śnieżnik metagranite (= augen gneiss) was metamorphosed at lower temperature and pressure conditions than the Gieraltów gneisses and that rocks of the two formations were zonally mylonitised, we do not see arguments which would substantiate the relationship proposed by Chopin et al. (2012a).

Summing up, the above review indicates that rocks of the Gierałtów and Śnieżnik formations systematically differ in many respects, starting from their protoliths. Although minor, all these differences are clearly in conflict with the assumption that they come from one igneous suite derived from identical source rocks. Our observations concur with those performed by Borkowska et al. (1990) and Borkowska (1994, 1996).

\section{PREVIOUS ISOTOPIC AGE DATA FOR GNEISSES} WITH BASIC REFERENCE TO OTHER ROCKS

An early isotopic study of the Śnieżnik augen gneiss yielded the Rb-Sr whole-rock age of $487 \pm 11 \mathrm{Ma}$, which was interpreted to indicate the time of emplacement of its granitic precursor (van Breemen et al., 1982). Later studies performed by Borkowska et al. (1990) yielded $\mathrm{Rb}-\mathrm{Sr}$ whole-rock isochron ages of $395 \pm 35 \mathrm{Ma}$ for the Śnieżnik gneisses and of $464 \pm 18 \mathrm{Ma}$ for the Gieraltów gneisses. These authors, based on the field relationships, the presence of retrograded eclogite bodies and unusually composed garnet, concluded that the Gierałtów gneisses were metamorphosed and deformed before "having been penetrated by the Śnieżnik porphyroid granite intrusion".

Lange et al. (2005) performed more $\mathrm{Rb}-\mathrm{Sr}$ analyses and having recalculated the results of Borkowska et al. (1990) came to the dates of $471 \pm 35 \mathrm{Ma}(n=7 ; \mathrm{MSWD}=29)$ for the Śnieżnik 
and of $449 \pm 5$ Ma $(n=21 ;$ MSWD $=43)$ for the Gieraltów gneisses. They confirmed earlier observations of variations in the $\mathrm{Rb}-\mathrm{Sr}$ isotope systematics throughout the dome and, considering the high MSWD values, suggested primarily a heterogeneous source for the gneisses and/or disturbances in the $\mathrm{Rb}-\mathrm{Sr}$ system being accomplished during subsequent metamorphism. The latter conclusion presumably also extends to other isotope systems studied in the OSD rocks.

The $\mathrm{Rb}-\mathrm{Sr}$ phengite and biotite ages for gneisses of the two formations range between $335 \mathrm{Ma}$ and $\sim 319 \mathrm{Ma}$ (Borkowska et al., 1990; Lange et al., 2005) and are well compatible with the Ar-Ar ages determined between $341 \mathrm{Ma}$ and $320 \mathrm{Ma}$ (Maluski et al., 1995; Marheine et al., 2002; Glascock et al., 2003; Schneider et al., 2006). These are cooling ages, yet often considered to reflect the timing of Variscan metamorphism in the gneisses.

A database of U-Pb zircon ages for the gneisses, still small though larger than the Rb-Sr database, shows three discrete age groups revealed mainly by SHRIMP analyses: (1) $560-530 \mathrm{Ma}$ and older up to $2.6 \mathrm{Ga}$, (2) 515-480 Ma, and (3) 350-330 Ma (Oliver et al., 1993; Klemd and Bröcker, 1999; Kröner et al., 2000; Turniak et al., 2000; Lange et al., 2002, 2005; Štípská et al., 2004; Grześkowiak et al., 2005; Bröcker et al., 2009, 2010). Group (1) is taken to represent inherited components, group (2) - magma formation and granite emplacement, group (3) - metamorphism and deformation of granites to gneisses. Such clear-cut picture is distorted by far less frequent ages around $450 \mathrm{Ma}$ and $370 \mathrm{Ma}$, yielded mainly by ID-TIMS analyses. These can be likely discarded as geologically meaningless mixed ages (groups 1 and 2) being derived from zoned single grains (Lange et al., 2005). However, disturbances in the U-Pb system during later metamorphism cannot be ruled out as the age numbers coincide with the $\mathrm{Rb}-\mathrm{Sr}$ ages of $\sim 460-450 \mathrm{Ma}$, which apparently resulted from disturbances in the Rb-Sr system.

The Th- $\mathrm{Pb}$ analyses of monazite from the gneisses disclose four age groups: (1) $\sim 500 \mathrm{Ma},(2) \sim 370-360 \mathrm{Ma}$, (3) -345-330 Ma and (4) 300 Ma (Gordon et al., 2005; Schneider et al., 2006). Groups (1) and (3) agree with magmatism in the Late Cambrian and subsequent metamorphism in the Early Carboniferous as inferred from other isotope systems. The ages of $2370-360 \mathrm{Ma}$ and $300 \mathrm{Ma}$ are not observed in the U-Pb zircon dataset for the gneisses.

Although $(\mathrm{U}) \mathrm{HP}$ rocks are beyond the scope of this paper, yet the Gieraltów gneisses enclose granulites whose garnet yielded Lu-Hf age of $382 \mathrm{Ma}$ (Anczkiewicz et al., 2007) hinting to the Devonian HP event. Budzyń et al. (2015) inferred, however, from the Th-U-total-Pb dating of monazite and P-T estimations that granulites were under temperature $>900^{\circ} \mathrm{C}$ by $349 \pm 2 \mathrm{Ma}$. Under such conditions, the isotope systems in most minerals must have been reset. Thus the $\sim 350$ Ma ages may only reflect the time of the resetting or the end of the metamorphic climax at best. Strikingly similar conclusion was reached by Brueckner et al. (1991) who studied the Sm-Nd system in eclogites and found that they were actually on the retrograde P-T path between $350 \mathrm{Ma}$ and $329 \mathrm{Ma}$.

The age of $\sim 350 \mathrm{Ma}$ is also identical with the metamorphic climax after the main deformational event in mica schists that occurred at $2352-346$ Ma (Gordon et al., 2005; Jastrzębski, 2009; Jastrzębski et al., 2010) and at $2360 \mathrm{Ma}$ in rocks of the borderland between the Saxothuringian/Moldanubian and Brunovistulian terranes along the eastern margin of the Orlica-Śnieżnik Dome (Jastrzębski et al., 2015). Relicts of the blueschist facies metamorphism in the western limb of the dome would imply that at least part of the metasedimentary rocks, which mantle the gneissic core of this unit, was subjected to $\mathrm{HP}$ conditions of $\sim 20-21 \mathrm{kbar}$ at $500-550^{\circ} \mathrm{C}$ (Faryad and Kachlík, 2013) prior to the thermal peak metamorphism at lower pressures.

As follows from the above, the timing and details of metamorphism and deformation in the OSD rocks are still not fully understood, thus should be debated (see Żelaźniewicz et al., $2014 a, b)$. Almost all isotopic studies yielded ages between $350 \mathrm{Ma}$ and $330 \mathrm{Ma}$, which suggests that the main tectonometamorphic processes in the dome occurred in the Early Carboniferous. However, the view presented in recent years, that all the following: prograde metamorphism up to HP-HT conditions associated with multiple folding and nappe emplacement, migmatisation, shearing and mylonitisation may have occurred almost contemporaneously with cooling of all rock types - requires many a priori assumptions and far more evidence. Moreover, having considered the presence of HP-HT eclogite and granulite enclosures in the Gieraltów gneisses, the former can be expected to be older or of the same age as the latter (Żelaźniewicz and Bakun-Czubarow, 2002). Actually, similar ages may indicate just common cooling of different rock units in the same time span.

GNEISS SAMPLES AND STRUCTURAL TEMPLATE

For the isotopic study, five samples were collected in the Międzygórze Antiform area (Fig. 1). They were selected to cover key variants of the two formations, each with different characteristics, structural position and evolution. Three samples represent the Gierałtów Gneiss Formation: OS40 - streaky gneiss (N50¹2'11.34" E16 $\left.45^{\prime} 36.28^{\prime \prime}\right)$, MD46 - porphyroblastic gneiss (N50¹4'1.74" E16²6'5.62"), OS35/8 - leucocratic neosome from migmatitic gneiss (N50¹3'44.53" E16 $\left.45^{\prime} 26.81^{\prime \prime}\right)$. Two samples come from the Śnieżnik Gneiss Formation: OS47 - weakly deformed rodded augen gneiss ( $\mathrm{L}>\mathrm{S}$ tectonite; N50¹3'21.18" E16 $\left.{ }^{\circ} 46^{\prime} 48.47^{\prime \prime}\right)$, and OS5 - enclave (xenolith) of migmatitic gneiss (N50 $13^{\prime} 21.21$ " $\left.\mathrm{E} 16^{\circ} 46^{\prime} 48.39^{\prime \prime}\right)$. The sequence of structures F1S1-F4S4 described below is valid for gneisses in the antiform (Redlińska-Marczyńska, 2011; Redlińska-Marczyńska and Żelaźniewicz, 2011).

Two Gierałtów gneiss samples (OS40, MD46) represent rocks with compositional banding (SO) followed mimetically by the earliest metamorphic foliation. Both the structures were folded (F1) and transposed (D1 event) to the axial planar foliation (S1) accompanied by shearing and intrafolial folds (Fig. 3A). The S1 was refolded into asymmetric F2 folds with variably oriented axial planar foliation S2 (Fig. 3B). In the hinge areas of $\mathrm{F} 2$ folds, there are K-feldspar (porphyro)blasts and/or leucocratic aggregates/neosomes composed of quartz, K-feldspar, white mica (and minor plagioclase, biotite, apatite). The presence of such structurally controlled blasts and neosomes is one of the characteristic and distinctive features of the Gierałtów Formation (Fig. 3B; see also Redlińska-Marczyńska and Żelaźniewicz, 2011: fig. 2.3). They appear as streaky porphyroblastic to migmatitic gneisses in which the leucosome was extracted in situ (nests) and/or injected as irregular veins in the axial planar or discordant manner (Fig. 3C, sample OS35/8). The migmatisation occurred syn- to post-kinematically with respect to disharmonic folding F2 (D2 event). Such tectonometamorphic edifice of the Gieraltów gneisses was then subjected to shear deformation and mylonitisation along S3 planes, which often were the rejuvenated or transposed S2 foliation (Fig. 3D). The shearing was associated with folding F3 (Fig. 3E) on roughly W-E to NW-SE axes and accompanied by 
stretching lineation (Fig. 4A, B) in the N-S to NE-SW direction $\left(D_{3}\right.$ event in both types of gneisses). In the Międzygórze Antiform, the subsequent event brought about conspicuous E-vergent folds F4 with amplitudes up to a few tens of metres (Fig. 3F), which resulted in subhorizontal and steep dips of the earlier S-planes (in both types of gneisses).

Sample OS35/8 is a leucocratic, unfoliated rock that comes from a subvertical vein which cuts discordantly the twice folded migmatitic gneiss of Gierałtów type (Fig. 3C). The vein continues as leucosome nests in these gneisses.

Sample OS47 is the rodded Śnieżnik gneiss with augens being K-feldspar porphyroclasts (Fig. 4A). In general, the augen gneisses developed from a porphyritic granite (Fig. 3A, B) with local pre-existing primary fabric (Żelaźniewicz 1984, 1988, 1991; Redlińska-Marczyńska, 2011). The granite was then heterogeneously deformed, some parts transformed into rodding gneiss ( $L>S$ to $L>S$ tectonites) with varied overprint (Fig. 4A, $B)$. This type of strain may have occurred in the hinges of F2 folds (Żelaźniewicz et al., 2013). Field observations show that such $L$ to $L>S$ fabric was then subjected to shearing which produced $\mathrm{L}<\mathrm{S}$ to S-type tectonites (Fig. 4B, C) thus changed the porphyritic granite to augen gneiss in which the shear zones widened as the deformation progressed. It was the very shearing that produced $D_{3}$ structures in the Gierałtów gneisses. In augen orthogneisses, the deformational history was evidently shorter and the first foliation-forming event in the Śnieżnik metagranite (Fig. 4A-C) did overprint the earlier folds and planar fabrics (S1 and S2) in the Gierałtów rocks (Fig. 3B, D, F). In the latter, the D3 shearing often rejuvenated the S2 foliation, which resulted in the spatial coincidence of the S2 and S3 planes.

Sample OS5 (Fig. 4D) comes from a large enclave $(\sim 10 \mathrm{~m} \times$ $15 \mathrm{~m}$ ) enclosed by the rodded $\mathrm{L}>\mathrm{S}$ augen orthogneiss of OS47 type (Fig. 4A). This is a coarse- to even-grained stromatitic migmatite with monomineral (K-feldspar or quartz) or polymineral (quartz $+\mathrm{K}$-feldspar \pm plagioclase) blasts, nests and pods that overgrew at random the folded migmatic fabric of this rock (Redlińska-Marczyńska, 2011).

\section{U-Pb ZIRCON STUDY}

\section{METHODS}

Zircon samples were retrieved from the five gneiss samples featured above, 5-7 kg each. They were prepared using standard procedures. Cathodoluminescence imaging was used to identify internal structure of zircon grains. The U-Th- $\mathrm{Pb}$ analyses were carried out using a SHRIMP II facility at the Research School of Earth Sciences, Australian National University, following the methods described by Williams (1998). 108 spots have been analysed in 97 zircon grains from five samples (Fig. 1). Each analysis consisted of six scans through the mass range, with the Temora reference zircon grains analysed for every three unknown analyses. The data have been reduced using the SQUID Excel Macro of Ludwig (2001). The $\mathrm{Pb} / \mathrm{U}$ ratios have been normalised relative to a value of 0.1859 for the Duluth Gabbro FC1 reference zircon, equivalent to an age of $1099 \mathrm{Ma}$ (see Paces and Miller, 1993). Uncertainty in the reference zircon calibration was $\pm 0.21 \%(2 \sigma)$ for the analytical session. Uncertainties given for individual analyses (ratios and ages) are at the one sigma level (Appendicies 1-5*). Correction for common $\mathrm{Pb}$ was either made using the measured
${ }^{204} \mathrm{~Pb} /{ }^{206} \mathrm{~Pb}$ ratio in the normal manner, or for grains younger than $800 \mathrm{Ma}$ (or those low in $\mathrm{U}$ and radiogenic $\mathrm{Pb}$ ) by the ${ }^{207} \mathrm{~Pb}$ correction method (see Williams, 1998). When the ${ }^{207} \mathrm{~Pb}$ correction was applied it was not possible to determine radiogenic ${ }^{207} \mathrm{~Pb} /{ }^{206} \mathrm{~Pb}$ ratios or ages. In general, the radiogenic ${ }^{206} \mathrm{~Pb}-{ }^{238} \mathrm{U}$ age for grains younger than $800 \mathrm{Ma}$ was used with correction by the ${ }^{207} \mathrm{~Pb}$ method. Tera-Wasserburg concordia plots, probability density plots with stacked histogram, and weighted mean ${ }^{206} \mathrm{~Pb}^{238} \mathrm{U}$ age calculations (Tera and Wasserburg, 1972) were carried out using ISOPLOT/EX (Ludwig, 2003); see Figures 5-9. Weighted mean ${ }^{206} \mathrm{~Pb}^{238} \mathrm{U}$ age calculation uncertainties are reported as $95 \%$ confidence limits.

\section{ZIRCON SAMPLES}

Zircon from porphyroblastic gneiss (Gieraltów Gneiss Formation): sample MD46. The zircon grains are 50 to $300 \mu \mathrm{m}$ long but many are short and almost isometric with bipyramidal terminations (Fig. 5). The CL images show grains with differently zoned interiors and less densely oscillatory zoned outgrowths (\# 1, 2, 6 and 7). In core domains, oscillatory, sector and planar zonal structures are in evidence (\# 1,5 and 14). Discontinuities between core and rim zones suggest discrete episodes of zircon crystallisation (\# 5, 6, 7, 9 and 15) and resorption (\# 15). Other grains have low-luminescent central domains surrounding old grains or inclusions (\# 4, 7, and 9), and localised recrystallisation can be seen (\# 5) around the latter. "Soccer-ball" zircon is also part of the population (\# 8).

Zircon from streaky gneiss (Gieraltów Gneiss Formation): sample OS40. Most grains are subhedral, subequant to slightly elongate ( 1:2). The CL images reveal complex internal structures of most grains that contain at least two different components (Fig. 6). Many grains display older, inherited, igneous or metamorphic cores (e.g., \# 11, 14) and oscillatory zoned rims (e.g., \# 3, 4, 11, 14), others have unzoned, clearly metamorphic rims (e.g., \# 5, 9, 10,15, and 16), but no high-U, dark rims have been observed. When seen under transmitted light, many grains are cracked and dark and some have mottled surfaces, which, along with rounded shapes (e.g., \# 1, 5), suggest surface transport and detrital provenance.

Zircon from a discordant leucocratic vein in the Gieraltów migmatitic gneiss: sample OS35/8. They are predominantly very clear, slender prismatic (aspect ratio 1:3 to 1:6), euhedral grains (Fig. 7). The presence of numerous long prismatic crystals (\# 3, 8,10,12 and 16), mainly with poor planar or sector zoning, differs this population from other two zircon samples retrieved from rocks of the Gierałtów Formation. Most grains have the $\{110\}$ prism faces that may imply crystallisation from relatively cold, $\mathrm{H}_{2} \mathrm{O}$ - and alumina-rich magmas and emplaced close to the place of extraction (Vavra, 1994). These would be in line with leucocratic neosome origin of their host vein. The CL images show oscillatory zoned internal structures. Discontinuities in such zoning are frequent, suggesting multiple zircon crystallisation episodes during growth of those grains. In some grains, there are clearly older inherited components in central areas which underwent dissolution. Other grains have a very poor CL response (greyish or whitish) and structure obliterated by metamict alterations. Slightly darker or CL bright overgrowths are less or quite poorly zoned. Few grains have thin dark CL rims (grains 18, 19, and 21).

Zircon from rodded ( $L>S$ ) augen orthogneiss of the Śnieżnik Formation: sample OS47. The zircon grains are elongate to almost equant, sub- to euhedral, $\sim 100-300 \mu \mathrm{m}$ 


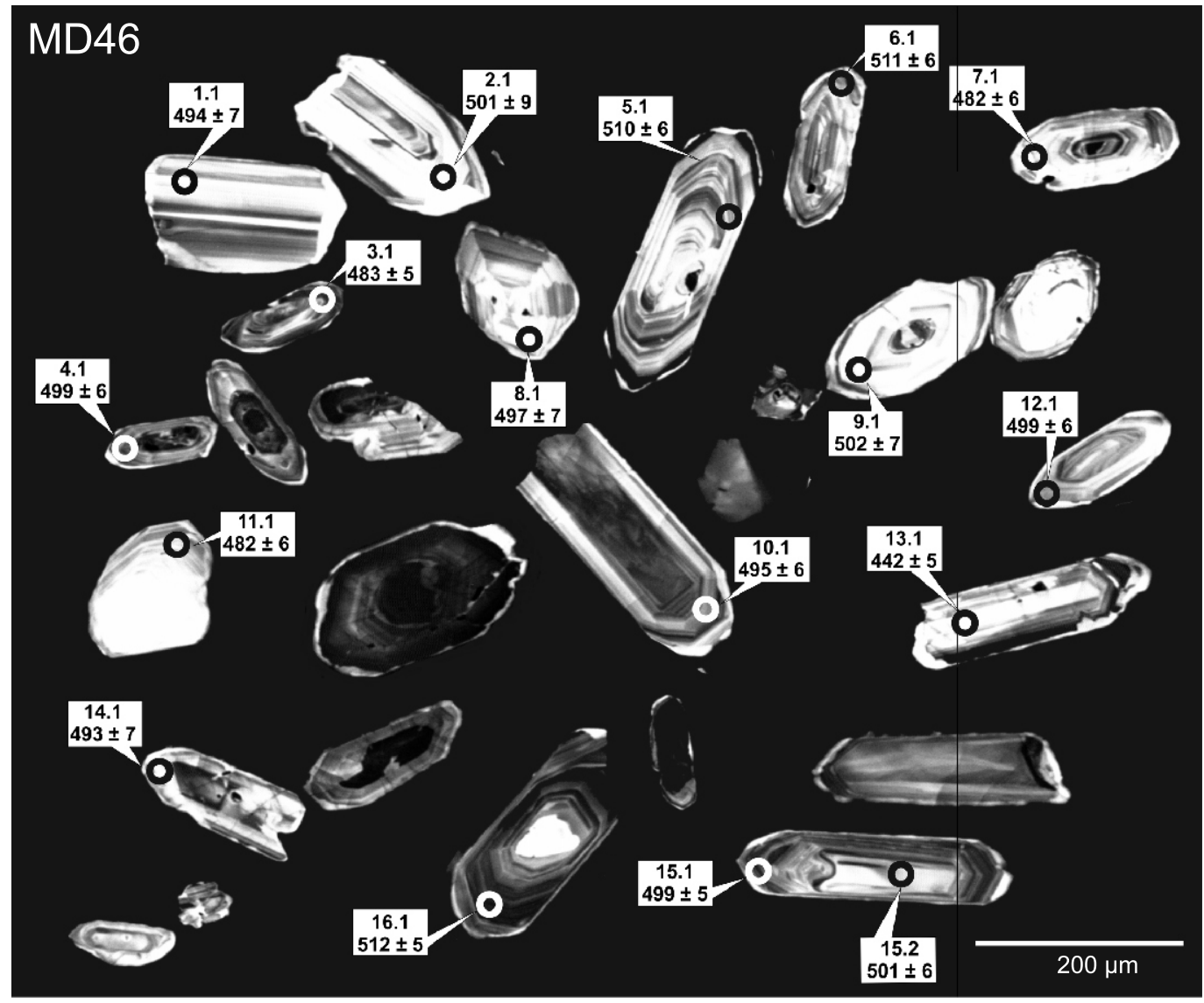

Fig. 5. Cathodoluminescent images of zircons from sample MD46

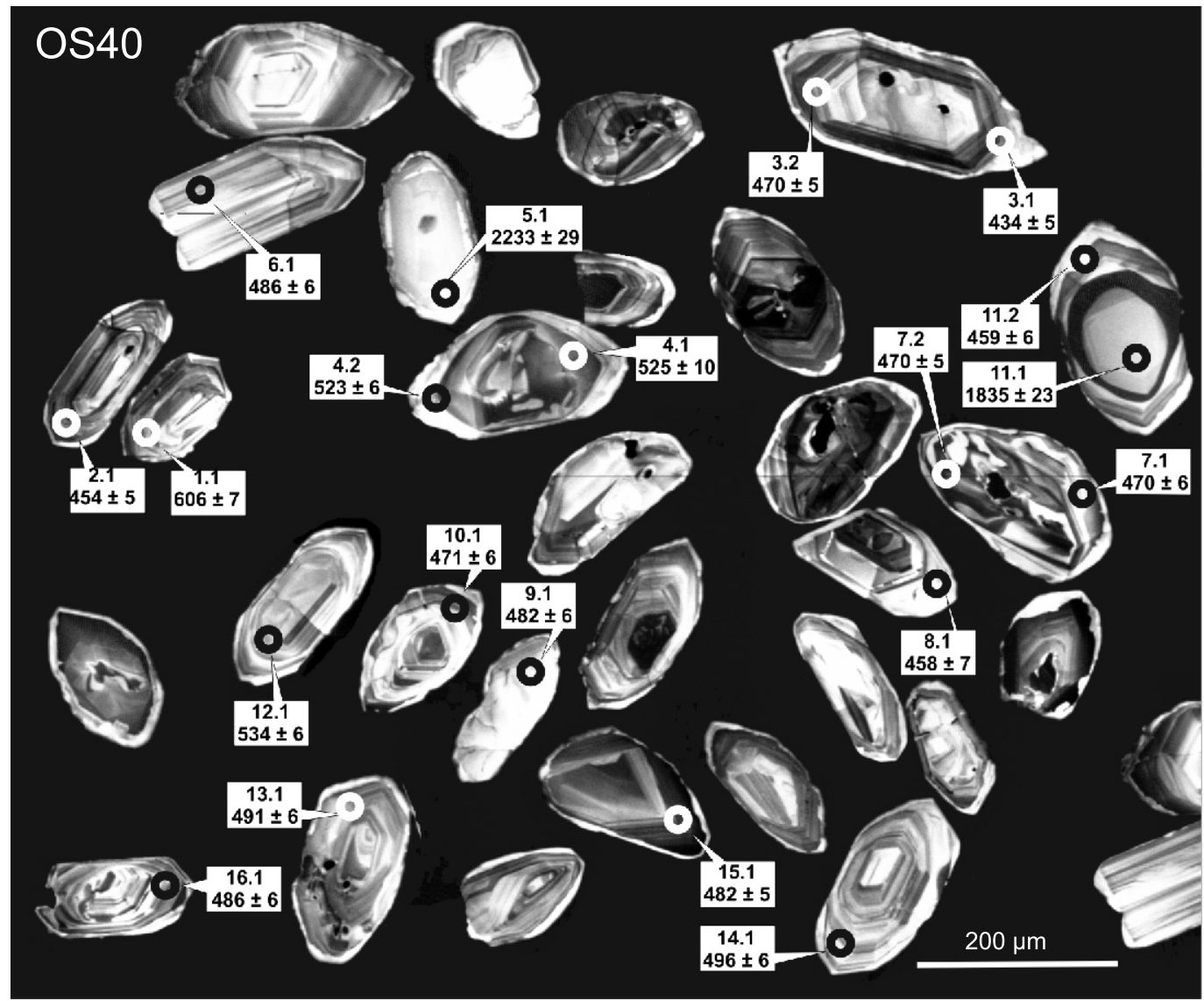

Fig. 6. Cathodoluminescent images of zircons from sample $0 S 40$ 


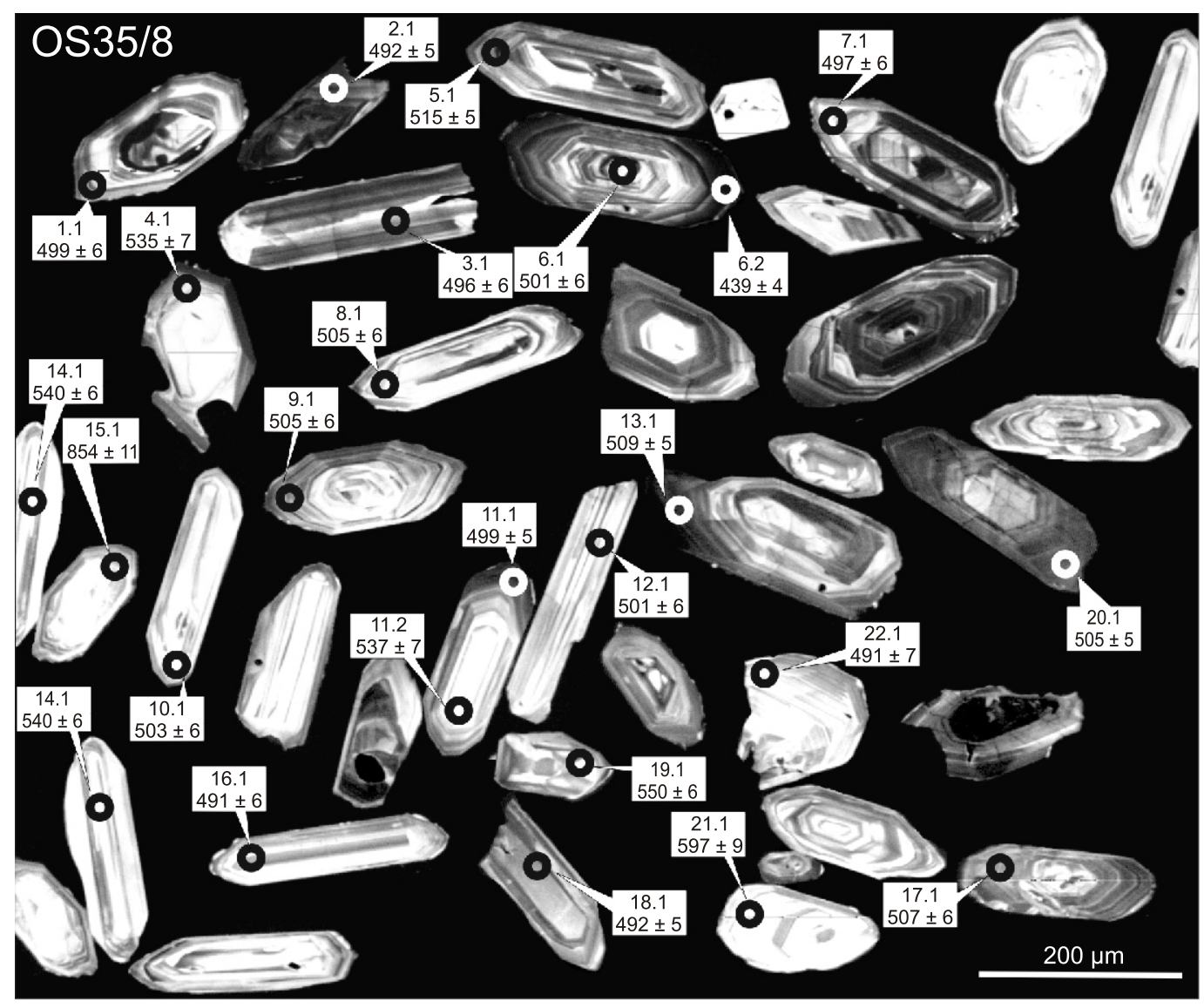

Fig. 7. Cathodoluminescent images of zircons from sample OS35/8

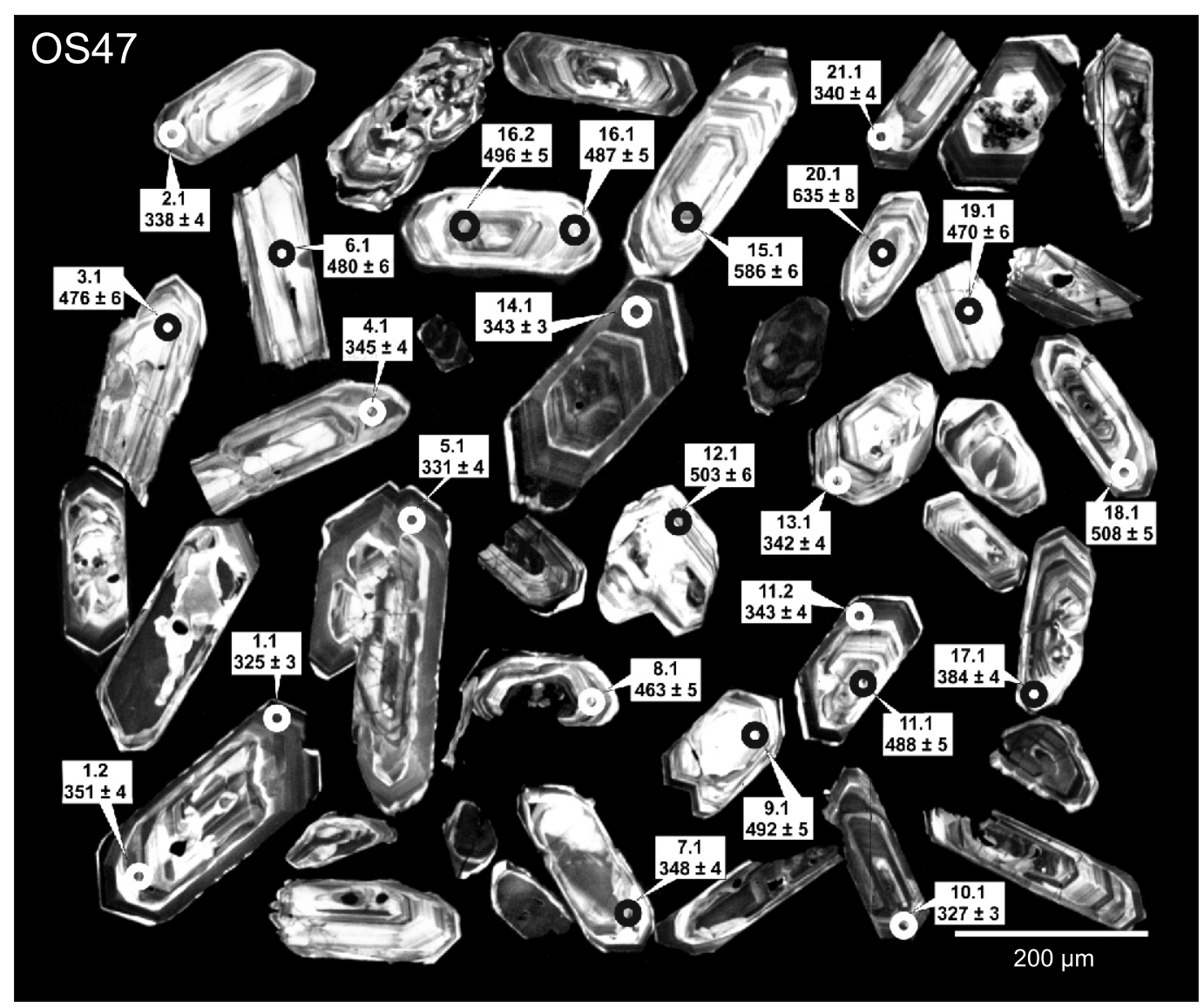

Fig. 8. Cathodoluminescent images of zircons from sample $0 S 47$ 


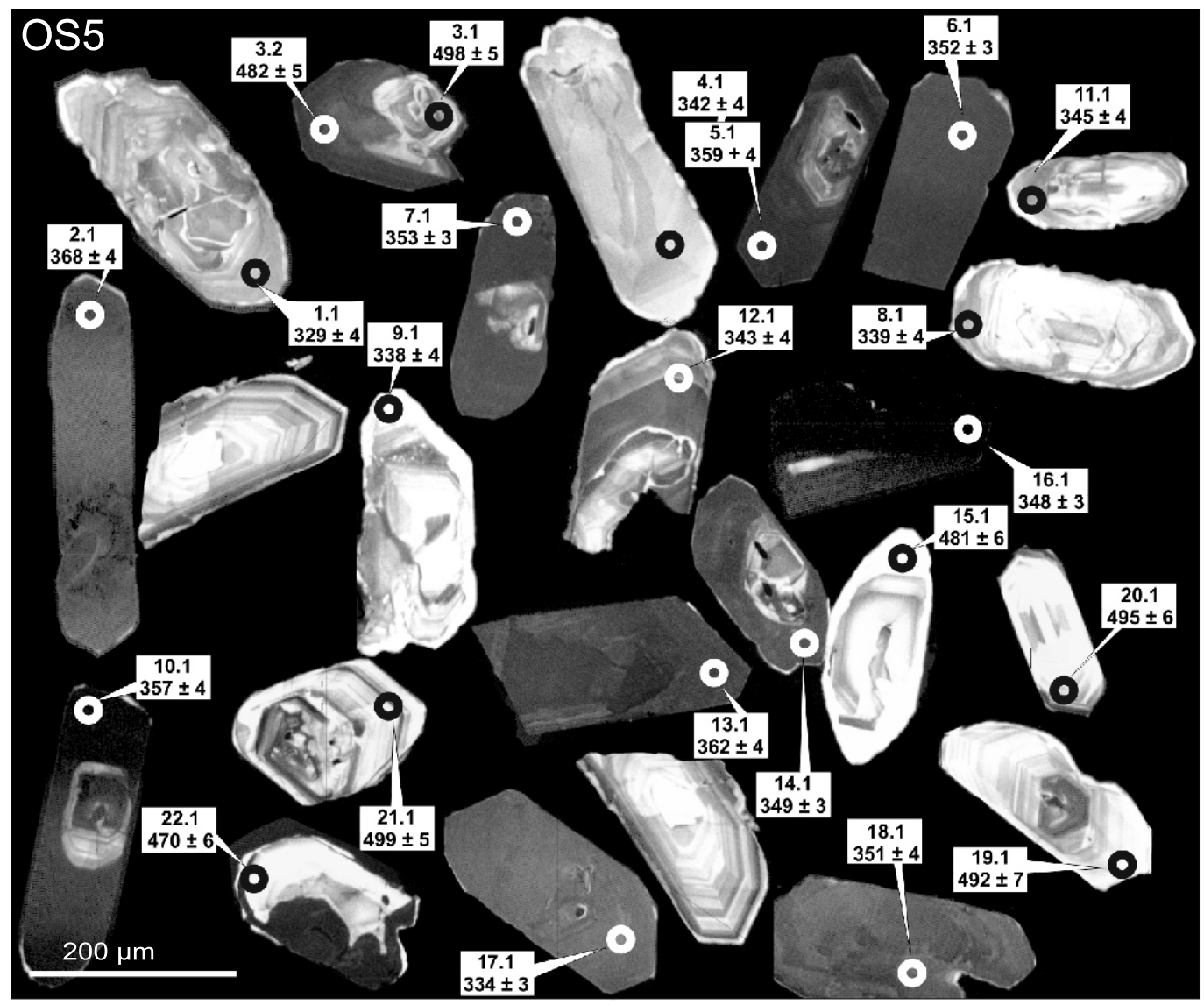

Fig. 9. Cathodoluminescent images of zircons from sample OS5

long, with both the $\{101\}$ and $\{211\}$ bipyramids (Fig. 8). Subround terminations (e.g., \# 15, 16) might be caused by metamorphic processes. Like in the OS35/8 leucosome, dominant $\{110\}$ prisms are in evidence. Many euhedral grains have irregularly structured or zoned inherited cores and oscillatory zoned outgrowths often darker in CL (e.g., \# 4, 5 and 14). The complex CL structure of the inner parts may indicate repetitive fluid or melt interactions that recrystallised and embayed the original inherited zircon component.

Zircon from migmatitic xenolith in the rodded augen orthogneiss of the Śnieżnik Formation: sample OS5. The zircon grains are $100-300 \mu \mathrm{m}$ long with variable aspect ratio 1.3:1 to 5:1 (Fig. 9). They differ from other samples by dullness due to metamictisation and strong dissolution of cores which have acquired very irregular outlines. Similarly to sample OS47, there are crystals terminated with the $\{101\}$ and $\{211\}$ bipyramids. In grains which have poor CL response (greyish or whitish), it is difficult to determine their structure. Some grains have bright oscillatory zoned centres and dark to black $\mathrm{CL}$ overgrowths.

RESULTS

Porphyroblastic gneiss (Gieraltów Gneiss Formation): sample MD46. In this sample, retrieved from the porphyroblastic gneiss, 17 oscillatory zoned areas were analysed on 16 zircon grains (Appendix 1 and Figs. 5, 10, 15). On the Tera-Wasserburg plot, the analyses form a single group around $500 \mathrm{Ma}$ (Fig. 10A). On a probability density plot, 10 analyses form a dominant age peak at $499 \pm 5 \mathrm{Ma}$, with 3 analyses each on the older and younger age side (Fig. 10B). The former, slightly older, could be considered as inherited zoned igneous zircon (i.e. the 3 older analyses at about $510 \mathrm{Ma}$ ) and the latter analyses likely relate to the loss of small amounts of radiogenic $\mathrm{Pb}$ (i.e. the 3 younger analyses at about $485 \mathrm{Ma}$ ). The analysis of grain 13 is significantly younger and we interpret the area analysed to have lost radiogenic $\mathrm{Pb}$. For the main oscillatory zoned component a weighted mean ${ }^{206} \mathrm{~Pb}^{238} \mathrm{U}$ age of $498.1 \pm 4.1 \mathrm{Ma}(n=10, \mathrm{MSWD}=0.21)$ provides an estimate for the time of major zircon crystallisation (see discussion below).

The analytical data show varying $\mathrm{Th} / \mathrm{U}$ ratios from 0.06 to 0.72 , of which $3 / 4$ (12 of 17 ) is below 0.3 , thus in the range of metamorphic zircons rather than magmatic, though unambiguous discrimination requires caution (Hoskin and Schaltegger, 2003). In the Tera-Wasserburg plot, the dispersed radiogenic ${ }^{206} \mathrm{~Pb}-{ }^{238} \mathrm{U}$ ages show a prominent grouping along a line that intersects the concordia at about $500 \mathrm{Ma}$ (Fig. 10A). However, no single igneous crystallisation event can be unambiguously inferred. The discontinuities in the oscillatory zoning indicate more than one crystallisation episode, whilst evidence of recrystallisation and resorption of central domains, and poorly zoned outgrowths suggest the importance of high-grade metamorphic processes. In grain 15, an age difference of $2 \mathrm{Ma}$, almost negligible if to consider error limits, would suggest a relatively short duration of such processes concurrent with the growth of oval, soccer ball-shaped crystals. This concurs with the host rock which is folded gneiss with K-feldspar porphyroblasts and polymineral aggregates located in the fold hinges due to incipient migmatitic/partial melting phenomena. 


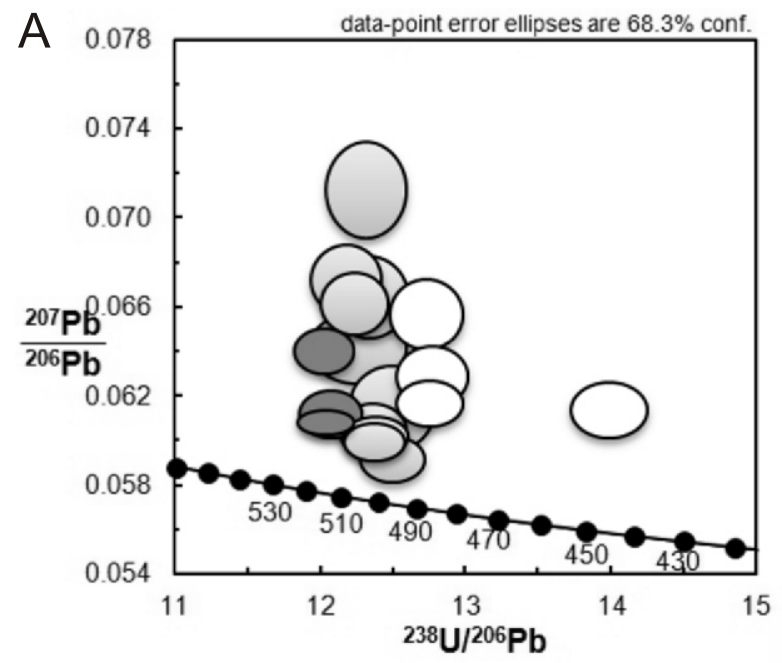

B

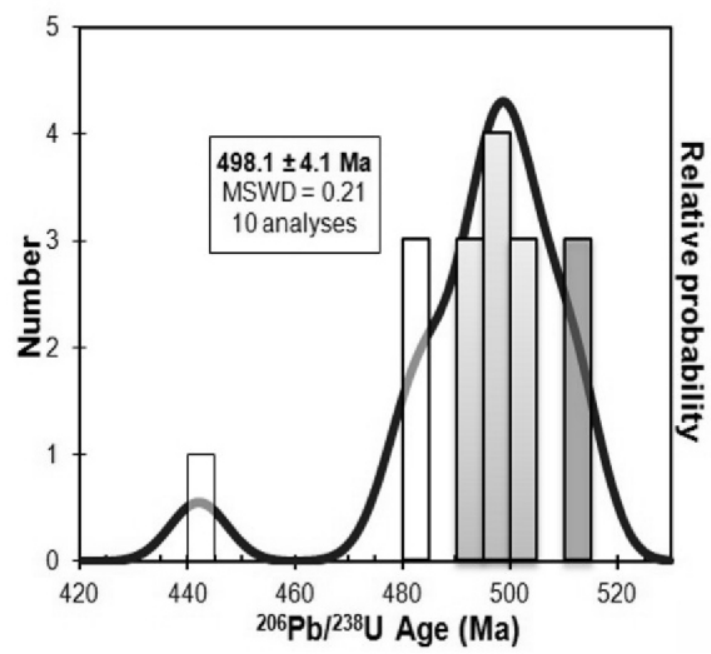

Fig. 10. Tera-Wasserburg concordia diagram $(A)$ and probability density diagram (B) for sample MD46

This and the following T-W plots show the calibrated, total ratios; i.e. uncorrected for common $\mathrm{Pb}$, whereas the probability plot shows corrected ages (2sigma). Each age grouping is represented by a different shade of grey

Such conditions likely promoted growth of zircon outer domains with oscillatory zoning as expected for the crystallisation from melt. Characteristically, the $T h / U$ ratios in such outgrowths vary remarkably from the lowest, "metamorphic" ratios $(<0.1)$ as old as $~ 512 \mathrm{Ma}$ to the highest, "magmatic" $(>0.5)$ as observed in the rim of grain 14.1 dated at $\sim 493 \pm 7 \mathrm{Ma}$. There are some legible relationships between age, texture and $\mathrm{Th} / \mathrm{U}$ ratios in zircons. Younger grains or domains tend to have higher Th/U ratios, which presumably reflects the trend from metamorphic to migmatitic/magmatic conditions at the $\sim 500 \mathrm{Ma}$ event. Again, this is well-illustrated by grain 15 , in which slightly older, homogenous yet partly resorbed core $(T h / U=0.09)$ is overgrown by oscillatory zoned outgrowth $(\mathrm{Th} / \mathrm{U}=0.26)$. The high common $\mathrm{Pb}$ content $(>1 \%)$ in $1 / 3$ of the analyses, ranging between $0.25 \%$ and $1.74 \%$, apparently did not make them useless.

Streaky gneiss (Gieraltów Gneiss Formation): sample OS40. For this study, 20 areas were analysed on 16 zircon grains (Appendix 2 and Figs. 6, 11, 15), coming from a streaky gneiss. In contrast to sample MD46, which also comes from the Gierałtów gneiss, no single age grouping is recorded. On the Tera-Wasserburg plot, the analyses scatter between $\sim 540$ and
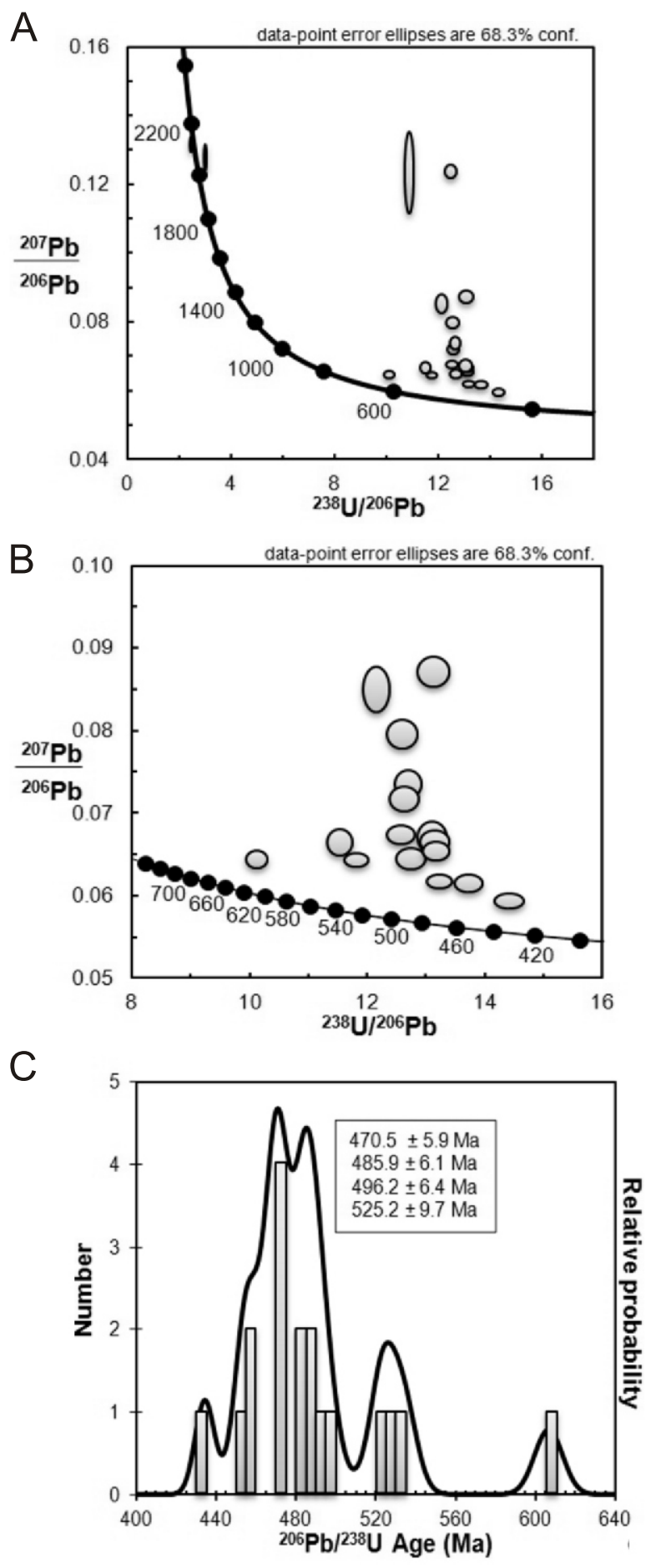

Fig. 11. Tera-Wasserburg concordia diagram (A), U-Pb concordia diagram for younger grouping (B), and probability density diagram (C) for sample

$\sim 440 \mathrm{Ma}$ (Fig. 11A), as a consequence of variable ${ }^{206} \mathrm{~Pb}^{238} \mathrm{U}$ ages and variable amounts of common $\mathrm{Pb}$. The latter is $>1 \%$ in 13 areas, which impedes any precise age determination and the analyses around $440 \mathrm{Ma}$ are apparently too young (Fig. 11B).

However, the strong dispersion in dates and correlation between $\mathrm{CL}$ structure and age, nor $\mathrm{U}$, Th and Th/U ratios, indicate the presence of a strong initially heterogeneous zircon population, coupled with superimposed metamorphic processes that 
gave rise to variable radiogenic $\mathrm{Pb}$ loss. Moreover, low $\mathrm{Th} / \mathrm{U}$ in almost all grains suggests that the complex structured zircon grains are metamorphic, which is in line with the observed convolute zoning and non-zoned or poorly zoned outgrowths in most grains. In this sample, like in MD46, no grain or rim was found which might record a Carboniferous event around $\sim 340 \mathrm{Ma}$. Based on the data in hand, there is no reason to assume that such profound metamorphic disturbances were caused by the event which did not left behind any legible trace. Although some conditions during metamorphism may impede or even prevent zircon recrystallisation, there is a poor reason to assume that they selectively operated only in the Gieraltów gneisses and not in the adjacent Śnieżnik gneisses (see samples OS47 and OS35/8). The complex nature of the OS40 zircon population along with the grains as old as $2.2 \mathrm{Ga}$ and $1.8 \mathrm{Ga}$, and the inferred detrital provenance of many grains allow us to conclude that the protolith to the studied Gieraltów gneiss is a metasedimentary rock with the maximum provenance age of $606 \mathrm{Ma}$ (\# 1) and possibly the youngest component of $\sim 540 \mathrm{Ma}$. It seems reasonable to infer that the protolith OS40 was metamorphosed in the span 540-440 Ma, most likely around $500 \mathrm{Ma}$ like other samples of the Gierattów gneisses (Fig. 11C). Despite high common $\mathrm{Pb}$, the integrated information on sample OS40 allows interpreting it as a high-grade paragneiss metamorphosed and deformed in Late Cambrian-Early Ordovician times. It is noteworthy that despite high $\mathrm{U}$ and high common $\mathrm{Pb}$ in many analyses the obtained age estimates fit exactly the ages provided in the literature by other authors for the Gierałtów and the Śnieżnik gneisses.

Discordant leucocratic vein in the Gieraltów migmatitic gneiss: sample OS35/8. From the leucocratic vein crosscutting the migmatite, 24 areas were analysed on 22 zircon grains (Appendix 3 and Figs. 7, 12). The Tera-Wasserburg plot shows distinct age groupings (Fig. 12A). For the main group, a weighted mean gives a ${ }^{206} \mathrm{~Pb}^{238} \mathrm{U}$ age of $500 \pm 3 \mathrm{Ma}(n=15$, MSWD = 1.08), which constrains the time of zircon crystallisation in the host leucocratic vein. Another group, represented by older grain cores, yields, as it might be expected, older ${ }^{206} \mathrm{~Pb}^{238} \mathrm{U}$ ages of about $540 \mathrm{Ma}(n=4)$. These analyses revealed $>1 \%$ of common $\mathrm{Pb}$ and do not provide precise age determination. The apparently youngest ${ }^{206} \mathrm{~Pb}^{238} \mathrm{U}$ age of $\sim 440$ Ma was determined for a high-U rim on grain 6 . It likely lost radiogenic $\mathrm{Pb}$ due to later metamorphic processes. The darker CL outgrowths with poor structure (\# 6, 13 and 20), which have between 1200 and $\sim 2000$ ppm U, display Th/U ratios between 0.04 and 0.08 as typical for metamorphic zircon. However, they may represent late-crystallizing igneous zircon from a $U$ rich magmatic pulse. The remaining areas analysed have rather poor oscillatory zoned structure and these, except two, have $\mathrm{Th} / \mathrm{U}$ ratios between 0.05 and 0.43 , thus $<0.5$ value over which zircon is typically assigned as igneous (Hoskin and Schaltegger, 2003). On the other hand, it is known that the Th/U ratio itself is not an unambiguous criterion. Interestingly, the long prismatic crystals which differ from other grains in the population, almost invariably yielded ages, within errors, around $\sim 500$ Ma (e.g., \# 3,10,12,16), though they contain high common $\mathrm{Pb}>1 \%$. Grain 11 developed the $\sim 500 \mathrm{Ma}$ outgrowth on the $\sim 540 \mathrm{Ma}$ central domain and the $500 \mathrm{Ma}$ outgrowths occur on other crystals, the cores of which have not been dated. The age of the cores and older grains is in the range from $\sim 600$ to $\sim 535 \mathrm{Ma}$, which sufficiently documents the inherited zircon even with imprecise timing. No legible evidence for a tectonothermal Carboniferous event occurs in the studied population. Narrow black rims on few grains are too thin and too U-rich to be dated (\# 6.2).
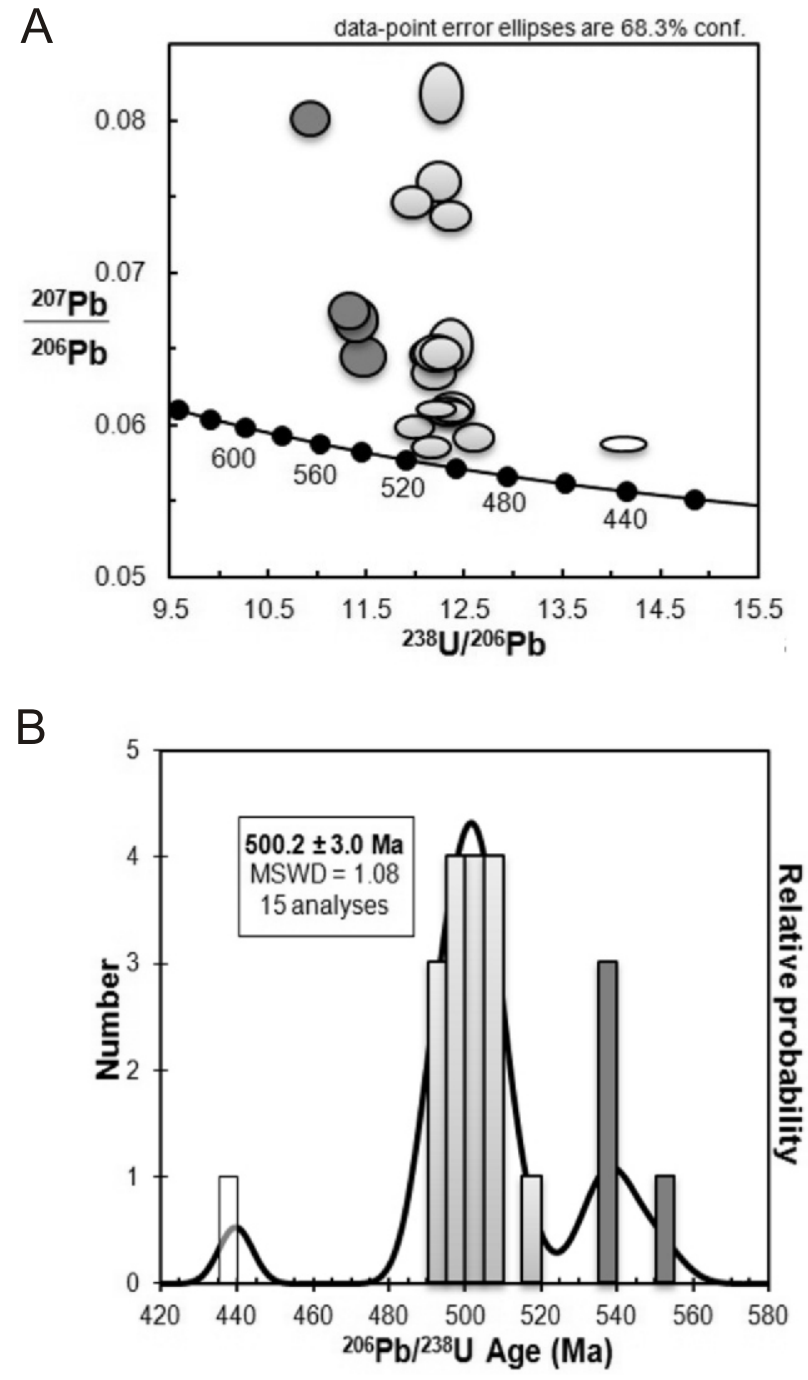

Fig. 12. Tera-Wasserburg concordia diagram (A) and probability density diagram (B) for sample OS $35 / 8$

Integrating the zircon data with the structural position of the host rock, a leucocratic unfoliated vein that discordantly intersects folded migmatitic gneiss of the Gieraltów Formation (Fig. 3C), the following inferences can be made: (1) discordant vein is younger than the deformed host gneiss; (2) zircon is inherited from the protolith with significant $\sim 600-540$ Ma component; (3) some old grains have no outgrowth or merely very thin $\mathrm{CL}$ black rims, which suggests that they have never been in an effective contact with the magmatic melt; (4) crystallisation from melt produced new, dominantly slender, prismatic grains and outgrowths on older grains at $500 \mathrm{Ma}$; leucocratic melt developed via partial melting of the host gneisses or rocks similar to them and represented larger portions of the mobilized migmatitic neosome; (5) zircon crystals dominated by the $\{110\}$ prisms typical of granites crystallised from $\mathrm{H}_{2} \mathrm{O}$-rich, "cold" magmas (Vavra, 1994); (6) such conditions likely characterized the neosome formation in the course of migmatisation observed in sample MD46, and presumably in the Gierałtów gneisses in general. Incipient migmatisation was accomplished under structural control, as evidenced by the fold-hinge located porphyroblasts, leucocratic aggregates and leucosome segregations or injections; (7) lack of signs of strain in the cross-cutting vein rock does not support the possibility that the 
twice folded host Gieraltów migmatite and the vein itself might have developed during the $\sim 340$ Ma episode of deformation and metamorphism of the $\sim 500$ Ma granite, as assumed by Turniak et al. (2000) and other authors following such view. Under some conditions, migmatisation may not bring about outgrowths on zircons, but it would be rather hard to assume that these occurred exclusively in the Gieraltów gneisses and not in the Śnieżnik gneisses which contain the $340 \mathrm{Ma}$ components, as exemplified by the two samples discussed below.

Rodded ( $L>S$ ) augen orthogneiss of the Śnieżnik Formation: sample OS47. In the sample retrieved from the Śnieżnik augen orthogneiss, 24 areas were analysed on 21 zircon grains (Appendix 4 and Figs. 8, 13). Two grains have old cores, $586 \pm 6 \mathrm{Ma}(\# 15)$ and $635 \pm 8 \mathrm{Ma}(\# 20)$, and those ages indicate inherited components. The ages obtained from core parts of other grains disperse around 507-487 Ma and also represent inheritance, yet younger. In grain 11 , the core yields an age of $488 \pm 5 \mathrm{Ma}$ with a Th/U ratio of $0.353 \mathrm{Ma}$, whilst the dark rim is distinctly younger being dated at $343 \pm 4$ Ma with a Th/ $\mathrm{U}$ ratio of 0.007 . Similar relationships are displayed by grain 1 . In these two grains, the core domains are distorted and embayed by darker and poorly zoned zircon of younger outgrowths. Such strong resorption of cores is even more obvious in other grains (\# 3, 4, 5, 7, 8 and 9) and is a predominant feature of most core-rim structured pairs. Th/U ratios in these rims are low, varying from 0.002 to 0.28 , with some systematic relationship between the ${ }^{206} \mathrm{~Pb}^{238} \mathrm{U}$ age and this ratio: the smaller Th/U ratio and higher U-contents the smaller age number (Fig. 13C).

In general, the low $\mathrm{Th} / \mathrm{U}$ ratios may be indicative of either growth from a partial melt being enriched in $U$, growth under high-grade metamorphic conditions, or growth from U-rich metamorphic fluids. The wide oscillatory zoned $\mathrm{CL}$ structure in the rims suggests, yet does not prove unambiguously, an igneous crystallisation event.

The high- $U$, low-Th dark CL rims (\# 5, 10, 14, 21) with low $\mathrm{Th} / \mathrm{U}$ ratios $<0.01$ yielded Carboniferous ${ }^{206} \mathrm{~Pb}^{238} \mathrm{U}$ ages that overall range from $\sim 343 \mathrm{Ma}$ to $\sim 325 \mathrm{Ma}$ with overlaps within errors. However, most analyses revealed high common $\mathrm{Pb}$. The dates are not precise, but we do not discard them as they fit well the age range determined by other authors for the OSD gneisses. The youngest ages do not necessarily always result from loss of radiogenic $\mathrm{Pb}$. In grain 1, the analysed area in the outgrowth (\# 1.1) is richer in $\mathrm{Pb}^{*}$ than the outer core. Within the 343-325 Ma group there is no clear relationship between age and contents of $\mathrm{Pb}^{*}$ or common $\mathrm{Pb}$ and these values differ considerably between grains.

A question arises as to whether the brighter $\mathrm{CL}$, oscillatory zoned zircon with Th/ $\mathrm{U}$ ratios of $0.016-0.023$ crystallised at about the same time as the darker $\mathrm{CL},<0.01 \mathrm{Th} / \mathrm{U}$ zoned rims. The age ranges overlap, but on the probability density plot of the youngest ${ }^{206} \mathrm{~Pb}-{ }^{238} \mathrm{U}$ ages there are two peaks, one at about $328 \mathrm{Ma}$ and another at $\sim 343 \mathrm{Ma}$. On the Tera-Wasserburg concordia plot (of the calibrated, total ratios; i.e. uncorrected for common $\mathrm{Pb}$ ) the three youngest analyses do not plot within uncertainty of the concordia curve but are elevated due to slight enrichment in common $\mathrm{Pb}$, and the possible radiogenic $\mathrm{Pb}$ loss cannot be excluded (Fig. 13A). The fact that there is overlap in ${ }^{206} \mathrm{~Pb}^{238} \mathrm{U}$ ages for the two components may indicate that the dominant weighted mean ${ }^{206} \mathrm{~Pb}-{ }^{238} \mathrm{U}$ age of $343 \pm 3 \mathrm{Ma}(n=7$, MSWD $=0.73$ ) is the best estimate for the time of crystallisation of the poorly zoned outgrowths.

In view of the above, a question arises about the origin of 343-325 Ma outgrowths: are they igneous or metamorphic fluid-assisted? As there is no grain with Carboniferous core, hence large amount of melt at that time seems improbable. The high $U$ coupled with the dark and clouded nature of a number of

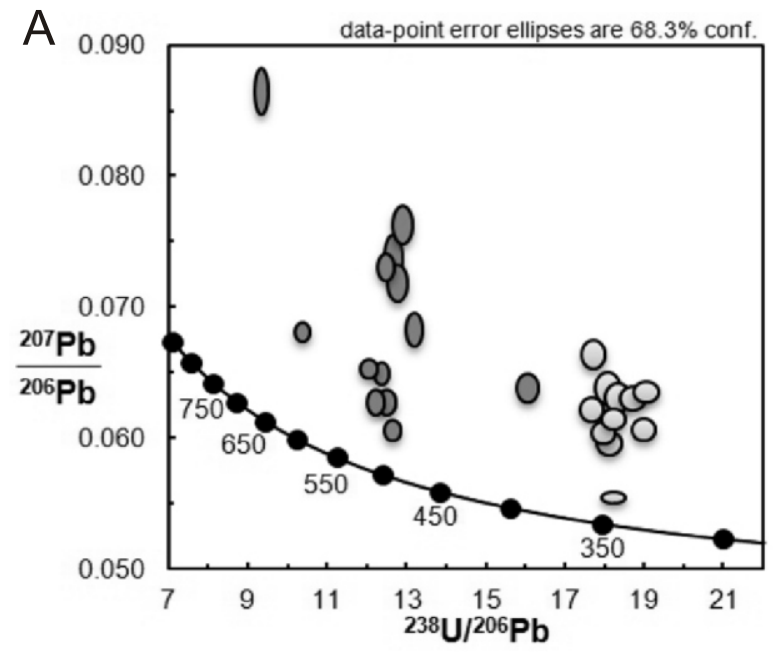

$B$


Fig. 13. Tera-Wasserburg concordia diagram (A), probability density diagram (B), and Th/U ratio vs. age [Ma] diagram (C) for sample OS47 
zircon grains in this population (though not for the areas analysed) is suggestive of metamorphic alteration and fluid activity. The corroded embayed outlines of usually strongly disturbed cores are in line with such option as are the low Th/U ratios.

It is noteworthy that an age group of $508-480 \mathrm{Ma}$ in the Śnieżnik metagranite (OS47), well-represented by the weighted mean ${ }^{206} \mathrm{~Pb}^{238} \mathrm{U}$ age of $497 \pm 6 \mathrm{Ma}(n=4$, MSWD $=0.24$ ), is similar to that shown by the zircons from the discordant leucocratic vein OS35/8. Indeed, in both rocks there are (1) inherited zircon components around $600 \mathrm{Ma}$ and (2) double core-rim structure of $\sim 500$ Ma grains with predominantly oscillatory zone inner parts and poorly zoned outgrowths.

A difference between samples OS35/8 and OS47 lies in the presence of the $\sim 340$ Ma zircon outer domains which were not observed in the former. In sample OS47, many 500 Ma grains have cores distorted and resorbed (e.g., \# 5, 9), which must have happened at the time when the $\sim 340$ Ma outgrowths were developing. Such resorption is absent from sample OS35/8 just because it was not affected by the $\sim 340$ Ma event (or less probably - conditions were unfavourable for the zircon to grow), and thus no trace of it is found there. The first statement is also evident from the concordia plots (Figs. 12 and 13). In the Tera-Wasserburg diagram for sample OS47, there is a group of analyses from undistorted grains with common $\mathrm{Pb}<1 \%$ (e.g., \# $16,18)$ that plots along a line which intersects the concordia at $\sim 500 \mathrm{Ma}$. Close to it there is another arrayed group of analyses of the distorted cores, often with common $\mathrm{Pb}>1 \%$, from the core-rim grains. These show slightly younger ages in the range $\sim 488-463 \mathrm{Ma}$ for the cores in the grains that possess the $\sim 340$ Ma outgrowths. It is clear that such younging of the distorted cores was due to alteration caused by later Zr-carrying fluids. In view of the above, the fluids were metamorphic rather than igneous. Indeed, neither the host rodded augen gneiss specimens, nor their microscopic images carry any evidence of the presence of magmatic melt which is unlikely to develop easily in such coarse-grained, poorly deformed metagranite (Fig. 4A).

Migmatitic xenolith in the rodded augen orthogneiss of the Śnieżnik Formation: sample OS5. Twenty-three areas were analysed on 22 zircon grains (Appendix 5 and Figs. 9, 14, 15) coming from a migmatitic xenolith enclosed within the Śnieżnik augen orthogneiss. As it was mentioned above (zircon sample section), the zircon population of grains is unlike in other four samples. The very irregularly textured central areas and those that are clouded by metamict alteration products have not been analysed. One third of the population (\# 3,15 , $19-22$ ) yielded ${ }^{206} \mathrm{~Pb}^{238} \mathrm{U}$ ages between $\sim 500$ and $\sim 480 \mathrm{Ma}$ for outer parts of the grains which have either oscillatory zoned igneous-looking cores (\# 19,21) or complex poorly zoned to non-zoned, highly distorted, metamorphic-looking cores (\# 3, 22). The outer parts are mainly poorly zoned. All these areas have high common $\mathrm{Pb}>1 \%$ and $\mathrm{Th} / \mathrm{U}$ ratios $\geq 0.14$ (up to 0.4 ), which is in the range observed for both igneous zircon and metamorphic zircons, yet not precise enough to permit unambiguous discrimination. Such characteristic is similar to that of sample OS47 from the Śnieżnik gneiss. These analyses do not yield precise dates, but we should not discard them. They are informative enough to discern a group of zircons that possess poorly zoned metamorphic-looking rims developed at $\sim 500 \mathrm{Ma}$ age, which were dissolved and strongly distorted during younger metamorphic overprint.

In grains with strongly distorted cores, the outer areas yield Carboniferous ${ }^{206} \mathrm{~Pb}^{238} \mathrm{U}$ ages and have $\mathrm{Th} / \mathrm{U}$ ratios mostly $\leq 0.011$, but with some ranging up to 0.05 . The $U$ concentrations in these grains/areas are quite variable in accord with the CL response. The dark CL areas mostly have more than 3000 ppm $\mathrm{U}$, ranging up to about $6500 \mathrm{ppm}$, whilst the bright areas gener-



$B$

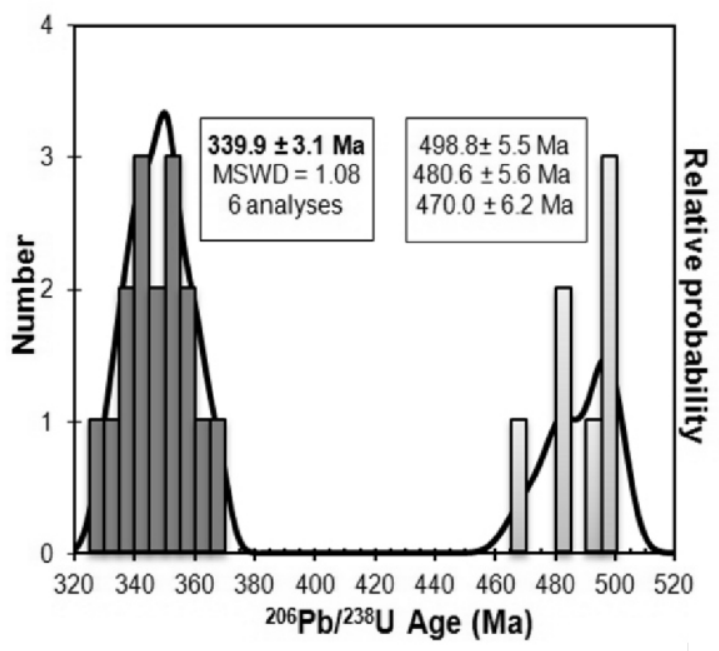

C

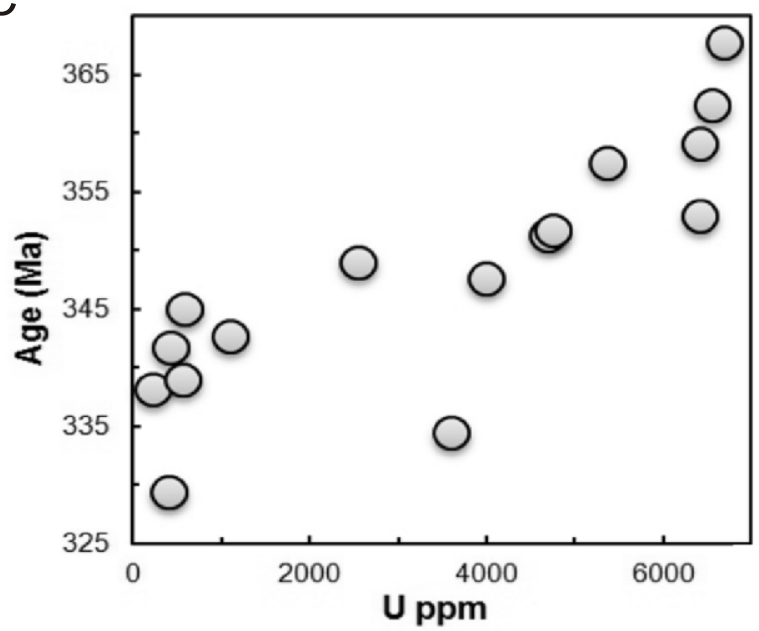

Fig. 14. Tera-Wasserburg concordia diagram (A), probability density diagram (B), and $\mathrm{U}$ ppm vs. age [Ma] diagram (C) for sample OS5 
ally have less than 600 ppm. On a plot of $U$ ppm versus ${ }^{206} \mathrm{~Pb}^{238} \mathrm{U}$ age (Fig. 14C) there is a positive correlation between ${ }^{206} \mathrm{~Pb}^{238} \mathrm{U}$ age and $\mathrm{U}$ ppm (starting from ca. $4000 \mathrm{ppm}$ of $U$ ), though opposite to that found in sample OS47. This is a common feature observed in SHRIMP analyses of very high-U zircons (see Williams and Hergt, 2000); there is a sputtering bias with $\mathrm{Pb}$ preferentially enriched over $\mathrm{U}$ in such extremely $\mathrm{U}$-rich zircon areas. It is also likely that there has been radiogenic $\mathrm{Pb}$ loss in such high- $U$ areas and this may counter the sputtering bias such that arbitrarily useful U-Pb dates can be obtained. Notwithstanding this fortuitous situation, if the extreme U-rich areas are excluded, a weighted mean ${ }^{206} \mathrm{~Pb}^{238} \mathrm{U}$ age of $340 \pm 3 \mathrm{Ma}(n=6, \mathrm{MSWD}=1.08)$ provides an estimate for the rim and overgrowth components in this sample. The analysis of grain 1 at $\sim 330 \mathrm{Ma}$ is younger and the area analysed is interpreted to have undergone radiogenic $\mathrm{Pb}$ loss. However, it should be noted that this spot has the lowest Th content ( 2 ppm).

Summing up the observations collected in sample OS5, this is exactly what may have occurred and be expected in a migmatised paragneissic xenolith that was entrapped on intruding granitic magma (age of $\sim 500 \mathrm{Ma}$ ) and then subjected to metamorphic overprint at $\sim 340 \mathrm{Ma}$. It is to be stressed that OS5 is not part of the Gierałtów Gneiss Formation. It is the xenolith of the migmatitic gneiss which is similar to Gierałtów, but does belong to the Śnieżnik Formation.

\section{DISCUSSION}

\section{ZIRCON MORPHOLOGY}

Most of the zircon grains analysed by us show core-to-rim oscillatory zoned structure. The xenocrystic cores range from clear, uniform prismatic grains with oscillating zonation to subround grains with relics of oscillatory, sector or planar zoning. Newly formed zircon rims may be in optical continuity or separated from the cores by more or less legible discontinuities, across which they differ in crystallographic orientation. Such discontinuities may have developed during interactions between crystal faces and younger fluids, whether magmatic or metamorphic. The activity of the latter was possibly enhanced by tectonic deformation.

Moreover, there are differences between samples from the Gierałtów and Śnieżnik formations. In the Śnieżnik augen gneiss (OS47) and in the migmatitic xenolith (OS5) enclosed within it, numerous grains have cores with distorted internal structure and convolute, sector or oscillatory zonation. These cores have highly irregular, embayed or broken outlines being surrounded by dark or bright in CL, poorly oscillatory zoned to non-zoned outgrowths (Figs. 8 and 9).

Such features are usually taken to indicate resorption, corrosion and dissolution processes occurring before and/or during the development of the overgrowths under both magmatic and metamorphic conditions. Having considered isotopic data, $\mathrm{CL}$ images of zircons, petrological characteristics, field relationships and structural features of the host rocks, we are in favour of the metamorphic/migmatitic conditions to explain the evolution of the host rocks for samples OS47 and OS5.

In general, the above features can also be linked to various stages of complex magma evolution from the initial formation by source melting, migration through the crust, to magma mixing fractional crystallisation and differentiation. In case of the Śnieżnik orthogneisses, the extensive presence of the $\sim 340 \mathrm{Ma}$ new zircon outgrowths interpreted as the product of magmatic crystallisation would require that the Śnieżnik magma intruded at that time. Such corollary is entirely incompatible with the local geology and other results of isotopic studies. Conversely, all these features can also develop during various stages of crystallisation from a locally derived melt (migmatitic) or hot supercritical fluids (in this case U-rich) interacting with the rock at the peak or high-grade metamorphic conditions, usually in the presence of an active aqueous phase (see Gebauer et al., 1997; Corfu et al., 2003; Geisler et al., 2007). In very fluid-rich systems, newly formed components will crystallise with usual characteristics of magmatic zircon; i.e. with similar morphology (euhedral/subhedral shape) and zoning (oscillatory). Morphology and textures of magmatic and migmatitic zircons in peraluminous rocks may be undistinguishable (Hoskin and Schaltegger, 2003) and we do not have a simple distinguishing criterion for the origin of dated zircons. Therefore, we see the need for integrating data collected along various lines of evidence. In our opinion, all the collected data favour the migmatitic hypothesis for the zircon origin in the three studied samples from the Gierałtów Gneiss Formation.

In view of the above and the absence of noticeable traces of the $340 \mathrm{Ma}$ components in the three samples from the Gierałtów Gneiss Formation studied by us, we suggest that metamorphic transformations in the gneisses of the Międzygórze Antiform were not a wholesale process and thus they varied within this structure, being strongly assisted by hot, U-rich fluids. Our observations show that such fluids were likely to be more easily channelized through the coarse-grained metagranite with strong constrictional fabric ( $L>S$ tectonite) than through the multiply deformed Gieraltów gneisses with the twice folded planar fabrics. Such explanation is in line with the lack or scarce presence of very thin dark CL rims, which might record weak Carboniferous overprint in these rocks.

\section{STRUCTURAL RECORD VERSUS GEOCHRONOLOGY}

The brief structural review presented in this paper (see above) indicates that the Gieraltów (migmatitic) Gneiss Formation has undergone more complex evolution (D1-D4) than the Śnieżnik augen orthogneisses (D2?/D3-D4). Samples of the streaky (OS40) and porphyroblastic (MD46) Gieraltów gneisses (Fig. 3B, D) represent twice folded rocks, accompanied by syn- to post-tectonic migmatisation with respect to D2 (Redlińska-Marczyńska, 2011). The latter produced leucosomes of various shapes, leucocratic veins (sample OS35/8) and aggregates as well as K-feldspar blasts located in F2 fold hinges, and giving a porphyroblastic outlook (MD46) to streaky (OS40) or flaser Gieraltów gneisses.

Besides the differences between the Gieraltów and Śnieżnik gneisses in the features of zircon grains, also observed in zircon typology (Turniak et al., 2000), these rocks further differ with the presence of skeletal Ca-garnets (inherited xenocrysts), Si-rich phengites, ilmenite and high-Al titanomagnetite. The latter can be interpreted as indicators of HP-HT episode inferred for the Gieraltów Gneiss Formation (Borkowska et al., 1990; Bröcker and Klemd, 1996; Grześkowiak, 2004; Stawikowski, 2006; Redlińska-Marczyńska and Żelaźniewicz, 2011; Chopin et al., 2012a) and thus in migmatitic xenoliths enclosed within the Śnieżnik metagranite.

In the twice folded and migmatised Gieraltów gneisses, the zircons yielded the mean ages of $500 \pm 3 \mathrm{Ma}$ and $498 \pm 4 \mathrm{Ma}$ for wide outer parts of the grains. As only few grains have very thin, dark in CL, metamorphic rims - probably of Carboniferous age - the question arises as to which of these zircon overgrowths 
reflect metamorphism and migmatisation in the gneisses: extremely thin and Th/U low rims, or rather voluminous, oscillatory zoned (igneous/metamorphic in appearance and higher Th/ $U$ ratio) $\sim 500 \mathrm{Ma}$ mantles. Again, having considered isotopic data, CL images of zircons, petrological characteristics and field relationships of the host rocks, the discordant leucocratic vein OS35/8 inclusive, we find the option of migmatisation of the Gierałtów gneisses at $\sim 340$ Ma rather unlikely and therefore we are in favour of the option of migmatisation at $\sim 500 \mathrm{Ma}$. Naturally, this does not preclude Carboniferous metamorphic overprint in rocks of the Międzygórze Antiform, however, more localized and less pervasive than is commonly thought (Turniak et al., 2000; Štípská et al., 2004; Lange et al., 2005; Bröcker et al., 2009). We do not support the view that the petrographic and mineral compositional variability of gneisses was mainly caused by modifications accomplished during deformation and migmatisation, as assumed by those authors.

The Śnieżnik augen gneiss in sample OS47 is $\mathrm{L}>\mathrm{S}$ tectonite, with genuine augen porphyroclasts derived from original K-feldspar phenocrysts during gneissification (Figs. 4A and 15). It developed at lower metamorphic conditions than those recorded by the Gieraltów migmatitic gneisses as indicated by higher Mn content in garnets, lower Al content in titanites, and lower Si content in phengites. Magmatic origin of this weakly deformed rock is evident from its mesoscopic and microscopic structural and petrographic features, which is corroborated by morphology of zircon grains, being oscillatory zoned and bright under CL (Figs. 8 and 15). Both cores and most of overgrowths in such grains yielded $\sim 500 \mathrm{Ma}$ age, interpreted to record the emplacement of a granitic precursor to the Śnieżnik augen gneiss. Similar results were obtained for the zircons from the migmatitic gneiss xenolith (sample OS5) enclosed within the Śnieżnik rodded $(L>S)$ orthogneiss. As xenoliths are to be at least slightly older than the host igneous rock, the observed geological relationships directly suggest that in the xenolith which was entrapped in the granite magma, most of the zircon grains carried by the gneiss became entirely resorbed, thus no inheritance was detected in the studied population. However, quite probably that more analyses would reveal older components too. Having confronted both the estimated age and features of the discussed zircons against the migmatitic nature and geological position of the gneiss xenolith, the corollary is that the latter must have undergone thorough zircon recrystallisation around $\sim 500 \mathrm{Ma}$, thus coevally with the formation and emplacement of the porphyritic precursor of the Śnieżnik augen gneiss. In case of the Międzygórze Antiform, this directly confirms the presence of rocks metamorphosed and migmatised at $\sim 500$ Maand indirectly the original differences between gneisses of the two formations, the view advocated by Redlińska-Marczyńska and Żelaźniewicz (2011).

Important information rendered by sample OS40 is that the Gierałtów Gneiss Formation is lithologically heterogeneous and comprises metasediments. Such conclusion sheds new light on the ongoing discussion on the origin of gneisses in the Orlica-Śnieżnik Dome and invalids the hypothesis about one magmatic source.

\section{CAMBRO-ORDOVICIAN TECTONOTHERMAL EVENT} ACCOMPANIED BY MIGMATISATION

The problem of Cambro-Ordovician event in the Orlica-Śnieżnik Dome was discussed by Lange et al. (2005), who did not find enough arguments to support migmatisation at that time. However, Prikryl et al. (1996) reported evidence for the pre-Variscan HT deformation and metamorphism in gneiss- es in the western part of the dome. Then Żelaźniewicz et al. (2006) described twice folded, fine-grained migmatitic gneisses which carried a later shear overprint at the contact with the Śnieżnik augen orthogneiss at the village of Zdobnice (Fig. 1). It was the very shearing that built up foliation in the metagranite. Deformation history of the latter is evidently shorter than in the migmatite. Such critical field relationships provide straightforward evidence that deformation and neosome formation in the migmatite occurred earlier than the common, yet heterogeneous shearing experienced jointly by the two types of gneisses. Elsewhere in the dome, such shearing was constrained with various methods to a span of $340-325 \mathrm{Ma}$ (review in Żelaźniewicz et al., 2014a, b). In Zdobnice, additional constraint comes from a discordant unfoliated syenite vein dated (U-Pb zircon) at $326 \pm 3 \mathrm{Ma}$ (Żelaźniewicz et al., 2006), thus the shearing there and the foliation build-up in the metagranite took place before $326 \mathrm{Ma}$, most probably between $\sim 340$ and $\sim 330 \mathrm{Ma}$. In view of the integrated field, structural and zircon data (Żelaźniewicz et al., 2006), it is rather unlikely that migmatites might have been selectively developed, folded, then sheared and dynamically recrystallised in the same time span. Therefore, an U-Pb age of $489 \pm 12 \mathrm{Ma}(n=12$, MSWD = 6.5) for the poorly zoned outgrowths, some dark in $\mathrm{CL}$, on older (Ediacaran-Early Cambrian) cores in zircon grains from a granitic neosome in the Zdobnice migmatite is interpreted as a record of migmatisation in the Late Cambrian-Early Ordovician. Although the precision of the date is not high, it is still good enough to indicate that the outgrowths can only be linked with tectonothermal processes which occurred at those times. Such view concurs with the fact that the studied zircon population does not contain evidence for any younger events which would lead to zircon mobilisation.

Bröcker et al. (2009) doubted the early migmatisation in Zdobnice by suggesting that the zircon grains in the neosome are residual and retained from the migmatised source rocks. This is probably very true and in no way invalidates the conclusion about the Cambro-Ordovician migmatisation in the twice folded gneisses from which the granitic neosome was derived. Although in the studied grains only $\sim 500 \mathrm{Ma}$ outgrowths were found. They provide the unambiguous evidence that zircon grains in these gneisses were extensively recrystallised at that time, because the rocks were just undergoing metamorphic transformations including migmatisation.

The above-mentioned situation in the Zdobnice migmatite (= Gierałtów gneiss) is similar to that observed in the studied samples from the Gieraltów Formation. The discordant leucocratic vein of sample OS35/8 is equivalent to the granitic neosome of the Zdobnice migmatite, whilst samples OS40 and MD46 represent the residuum or palaeosome. We reckon that correct interpretation of partially melted rocks requires not only $\mathrm{U}-\mathrm{Pb}$ zircon age and morphology information but also careful examination of the field relationships and structural history of the rocks under study. Such appropriately multi-aspect approach is particularly important while dealing with the complex gneiss core of the Orlica-Śnieżnik Dome with prolonged history (Fig. 15).

\section{CARBONIFEROUS EVENT}

In several recent papers that report results of the isotopic analyses of gneisses in the Orlica-Śnieżnik Dome, the general conclusion, based on isotopic age and chemistry, is that these rocks: (1) had common metasedimentary protolith, (2) came, possibly in a few batches, from a single magma source, (3) intruded to form an extensive granite body at $\sim 500 \mathrm{Ma}$, (4) were 


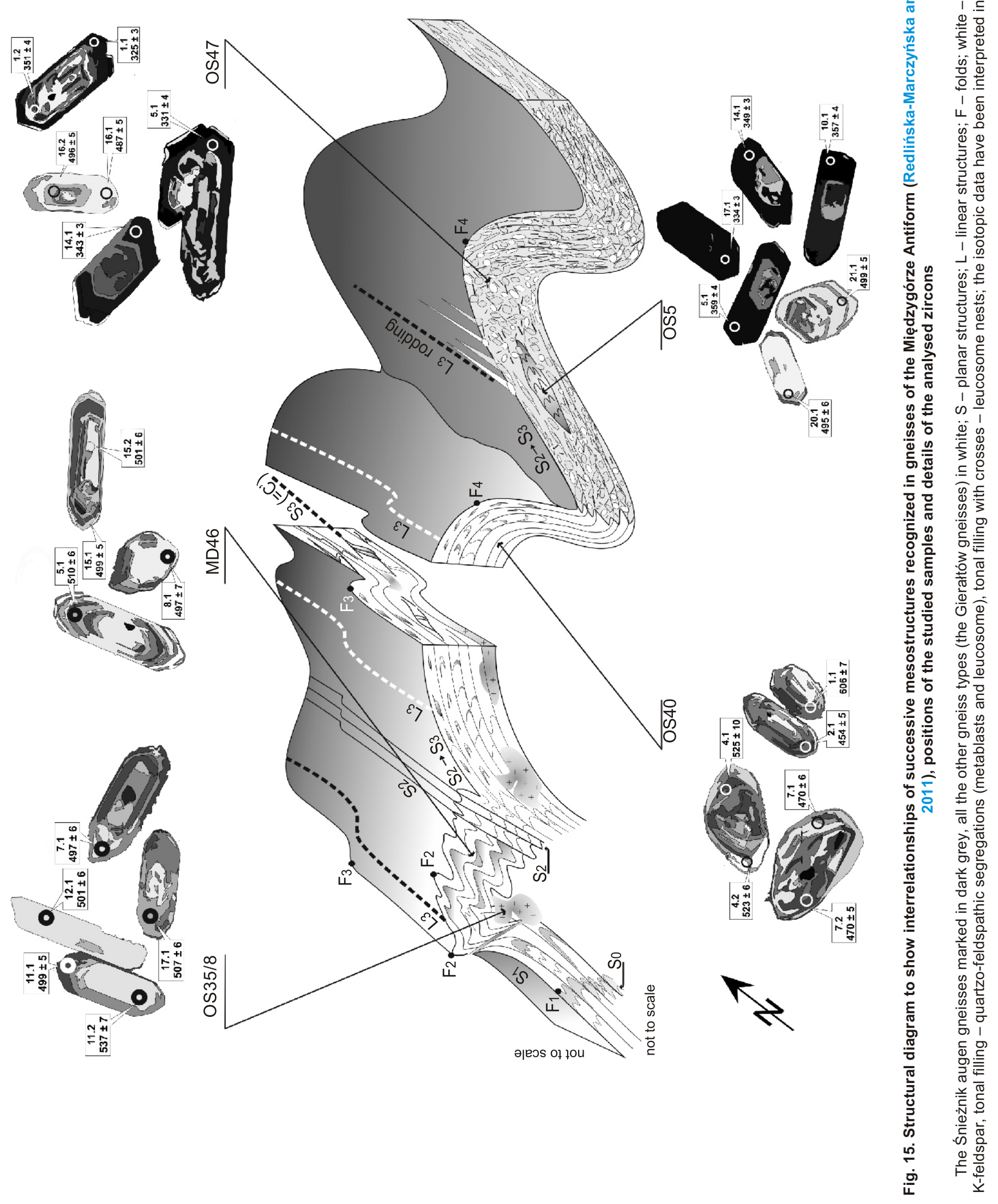


all transformed to gneisses from the original granites by diversified deformation, metamorphism and migmatisation that occurred around $\sim 340 \mathrm{Ma}$ (Turniak et al., 2000; Lange et al., 2002, 2005; Štipská et al., 2004; Bröcker et al., 2009). However, detailed integrated studies of the topics under point (4) are scarce. Very few papers present structural characteristics of the gneisses (Cymerman, 1997; Chopin et al., 2012a; Żelaźniewicz et al., 2013) and each deals with another aspect of it. A more integrated approach was attempted by Redlińska-Marczyńska (2011) and Redlińska-Marczyńska and Żelaźniewicz (2011), and needs to be continued.

This study shows that the problem of $\sim 340$ Ma migmatisation, which does not exist or is very minor in the three samples of the Gieraltów Formation, becomes quite apparent in two samples from the Śnieżnik Formation. In contrast to the Gieraltów samples, both the weakly deformed metagranite (OS47) and migmatitic xenolith (OS5) enclosed in it, rather surprisingly revealed the extensive presence of $\sim 340 \mathrm{Ma}$ zircon components in the form of thick rims. It appears as outgrowths on either undistorted or distorted and resorbed cores dated at $\sim 500 \mathrm{Ma}$. The most commonly observed features are irregular domains (convolutions, blurs and transgressive lobes) of homogeneous low-U zircon which cuts discordantly across the oscillatory zoned older domains (Figs. 8, 9 and 15). Such features are thought to develop by recrystallisation in the presence of aqueous fluids in deep-seated settings, for instance during late to post-magmatic cooling (Pidgeon and Compston, 1992; Nemchin and Pidgeon, 1997; Schaltegger et al., 1999), due to metamorphic recrystallisation in the solid state (Hoskin and Black, 2000; Corfu et al., 2003) or during the partial melting (Song et al., 2014). Younger ages in the range $\sim 488-463$ Ma for cores in such double structured grains were likely due to alteration caused by later Zr-carrying and significantly U-enriched fluids. Our interpretation of the new isotopic data is consistent with the structural observations and is not at odds with current knowledge about zircon behaviour and U-Pb systematics under various crustal processes.

Having reconciled the aforesaid information from the zircon systematics and morphology with the geological situation of these samples, we expect that the fluids were metamorphic rather than igneous. In the weakly deformed rodded augen gneiss and the xenolith, no evidence of the presence of magmatic melt was observed (Figs. 4A, B, D and 15) and the wide oscillatory zoned CL structure in the rims does not prove unambiguously crystallisation from a melt, either. A consequence of the opposite conclusion would be that the Śnieżnik granite crystallised from a melt that intruded at $\sim 340 \mathrm{Ma}$, which is extremely unlikely.

Following the lithologic-structural criteria for the classification of gneisses in the Orlica-Śnieżnik Dome - the one proposed by Redlińska-Marczyńska and Żelaźniewicz (2011) or even those used by Chopin et al. (2012a), there is no evidence in the Śnieżnik augen gneiss ( "type I" sensu Chopin et al., 2012a) that might be taken to support any igneous or partial melting event, or melt extraction after its granite precursor was emplaced in the crust. In contrary, the field evidence shows that migmatitic xenoliths were enclosed in the granitic protolith and these must have developed prior to, or coevally with the host granite, but not later than its final emplacement high in the continental crust.

In view of the above, we reckon that the situation observed in samples OS47 and OS5 is quite instructive. Taking into account the extensive metamorphic recrystallisation of zircon grains in the evidently least deformed and least transformed $\sim 500$ Ma metagranite in the Carboniferous, similar processes may be expected to have occurred in other felsic rocks and at other times. We do suggest that this is what actually took place and may be observed in the zircon populations retrieved from the three samples of the Gieraltów Formation, but the degree of recrystallisation and replacement was significantly higher in the Late Cambrian-Early Ordovician. Precursors of the Gierałtów rocks are likely to have been reworked at that time. Rocks akin to those of the Gieraltów Formation occur as xenoliths of various dimensions within the $\sim 500$ Ma Śnieżnik (meta)granites transformed to augen orthogneiss during the Variscan event.

\section{COMPARISON WITH PREVIOUS ISOTOPIC RESULTS}

It is worth to note that our results partly confirm those obtained by Turniak et al. (2000) for the Śnieżnik and Gieraltów gneisses in the Międzygórze Antiform. The two samples studied by them came from different locations than our samples, but it should be emphasized that sample OS47, although less gneissified, is similar to sample M10 of the Śnieżnik augen gneiss dated by Turniak et al. (2000). However, the $\sim 340 \mathrm{Ma}$ zircon components are much more abundant and more diversely represented in our sample. In their sample, only two analyses of high- $U$, black $\mathrm{CL}$ rims on $\sim 540 \mathrm{Ma}$ cores yielded ages of $327 \pm 15 \mathrm{Ma}$ and $336 \pm 7 \mathrm{Ma}$. The latter were interpreted as the timing of Carboniferous metamorphic overgrowths. Such interpretation actually concurs with ours.

In contrast, our results for the Gieraltów Formation rocks significantly depart from that of Turniak et al. (2000). It is not too surprising, given the discrepant gneiss classification used by different authors (review in Żelaźniewicz et al., 2014a, b). Judging from the published photograph and description of localisation, sample M16 collected by Turniak et al. (2000), although fine-grained, is a highly sheared and mylonitised gneiss which differs from the Gieraltów rocks studied by us. This gneiss is actually very similar to "type-III" mylonitic orthogneisses distinguished by Chopin et al. (2012b) but controversially interpreted by them as a HT-HP product of mylonitisation of the Śnieżnik granite. In our opinion, based on the detailed field observations and on the observed structural sequence in the Międzygórze Antiform (Fig. 15), the "type-III" orthogneisses are actually mylonites once entrapped by the Śnieżnik granitic magma and repeatedly sheared later jointly with the host metagranite. In other words, they are enclaves and thus their geological position in the Międzygórze Antiform is actually similar to that of the xenolith OS5. Having acknowledged this observation, the zircon systematics from our sample OS5 and sample M16 of Turniak et al. (2000) appear strikingly compatible. In both there are similar features: sector zoned or unzoned zircon cores, distorted and corroded cores with two age groups 540-500 Ma and $480-430 \mathrm{Ma}$ due to evident $\mathrm{Pb}^{*}$ loss, metamictisation, wide dark CL unzoned outgrowths, and thin black CL rims. Therefore, we propose that the geological reinterpretation for sample M16 may be similar to our sample OS5.

Our criticism to Chopin's et al. (2012b) attempt of classification of gneisses in the Międzygórze Antiform focuses on the unsatisfactory one-sided approach which neglected all earlier proposed classifications, including the major subdivision into the Śnieżnik and Gierałtów types. Three types of gneisses proposed by these authors differ by the amount of deformation and metamorphism in the arbitrarily assumed prograde transformation from initial granite. They estimated that the least deformed orthogneisses (= type I = Śnieżnik augen gneiss) underwent metamorphism at pressures $<15 \mathrm{kbar}$ and temperatures $<700^{\circ} \mathrm{C}$, whereas the other two types, more strongly deformed, equilibrated at $\sim 20 \mathrm{kbar}$ and temperatures $>700^{\circ} \mathrm{C}$. Not entering the problem of relevant geological models, such results suggest that the gneisses were metamorphosed under different conditions and at different depths. Field observations show, however, that they presently alternate in a single exposure as lenticular bodies even $<2 \mathrm{~m}$ thick (Fig. 3F), thus the question arises how they got into mutual contacts. 
Chopin et al. (2012a) proposed that the three types of gneisses were equilibrated at different P-T conditions along a prograde path during the burial of the continental crust. In contrast, Štípská et al. (2012) suggested that all the gneisses were formed and folded together with eclogites during the HP event and then, in the course of exhumation, were heterogeneously re-equilibrated with metastable leftovers in which HP mineral relicts were preserved. Not sharing fully this proposition, we suggest that such leftovers are among the enclaves once embraced by porphyritic granite magma. Our view is based on the studies of a variety of enclaves occurring within the Śnieżnik augen gneisses (Redlińska-Marczyńska and Żelaźniewicz, 2011). It is also consistent with the striking similarities between the xenolith sample dated by us and the rock analysed by Turniak et al. (2000).

Chopin's et al. (2012a) proposition assumes that gneisses got into the present metasedimentary surroundings by extrusion of migmatitic diapirs through steep crustal channels. Actually, this is a pretty old view, originally expressed by Don (1964) and further explored by Don et al. (1990, 2003), Štípská et al. (2004, 2012), Pressler et al. (2007), Schulmann et al. (2008) or Chopin et al. (2012b). However, the relevant steep or dip-plunging stretching lineation, to which these authors refer, has not been observed by us in the gneisses of the Międzygórze Antiform. In contrast, the subvertically oriented foliation does exist, however not in such channels, as suggested by these authors, but in the short, steep limbs of the E-verging folds (see Figs. 4B and 15; Redlińska-Marczyńska, 2011; Redlińska-Marczyńska and Żelaźniewicz, 2011; Żelaźniewicz et al., 2014a for details), which can hardly support diapirism in the antiform.

In general, our data confirm the earlier results which interpreted the Śnieżnik gneisses as a 500 Ma S-type granite (with heterogeneous $\sim 340$ Ma metamorphic overprint) ultimately derived from the mainly metasedimentary Neoproterozoic crust (600-540 Ma). Dates obtained from the xenocrystic zircon cores in the Gieraltów gneisses also point to the reworking of $\sim 635-535 \mathrm{Ma}$ (Cadomian) crust containing inherited 2.2-1.8 Ga components. Similar age clusters have been reported from the $485 \pm 12 \mathrm{Ma}$ Zdobnice migmatites in the western part of the Orlica-Śnieżnik Dome (Żelaźniewicz et al., 2006).

\section{GEODYNAMIC SETTING}

Although our analyses point to the significance of the $\sim 500$ Ma period, we treat this date as a record of a pronounced mid-term event rather in the process of longer duration. Taking into account other published data, even limited to U-Pb zircon ages only along with the error limits, it appears that the process might have presumably occurred between $\sim 513 \mathrm{Ma}$ (511 \pm 2 Ma, Kröner et al., 2000; $495 \pm 14$ Ma, Turniak et al., 2000; $507 \pm 17 \mathrm{Ma}$, Lange et al., 2005) and $476 \mathrm{Ma}$ (488 \pm $12 \mathrm{Ma}$, Żelaźniewicz et al., 2006; $491 \pm 12 \mathrm{Ma}$, Lange et al., 2005). Such $\sim 40$ m.y. long time span is of reasonable duration for an intraplate rifting and subsequent build-up of a magmatic arc accompanied by back-arc extension, which is the scenario commonly used to explain Early Paleozoic history of the Orlica-Śnieżnik Dome in particular, the Sudetes and the NE part of the Bohemian Massif in general. The Palaeo-Tethys Ocean subducted beneath the Gondwana plate, and the future dome was located at its margin in a magmatic arc position.

We expect that the Late Cambrian to Early Ordovician tectonothermal event, which included granitic intrusions and contractional deformation, was more significant and complex than hitherto thought. Similar observation was also reported from other parts in the Bohemian Massif. For instance in the Teplá Crystalline Complex, Peřestý et al. (2015) found evi- dence that the 505 Ma granite intrusion was followed by regional deformation and metamorphism in the country rocks already at $485 \mathrm{Ma}$, in a pre-Variscan event.

Given the data and arguments presented above, we propose that the two gneiss formations in the Orlica-Śnieżnik Dome were originally derived from Cadomian crustal rocks accreted to an active margin of northern Gondwana between 635 and $535 \mathrm{Ma}$. Rifting in a back-arc setting allowed deposition of the Młynowiec-Stronie Group sedimentary-volcanogenic succession, which ceased before the Late Ordovician (Jastrzębski et al., 2010; Żelaźniewicz et al., 2014a, b). The Cadomian crust was thinned and deformed, while mantle-derived heat led to its partial melting, migmatisation and anatexis. This process conceived the Gierałtów Gneiss Formation and eventually gave rise to calc-alkaline, K-rich, porphyritic, S-type granites with the supra-subduction signature (see discussion in Pin et al., 2007) that intruded at $\sim 515-475 \mathrm{Ma}$ as protolith of the Śnieżnik Augen Gneiss Formation. Such a scenario explains both the observed major isotopic and geochemical similarities and numerous minor, yet significant differences between rocks of the two formations. Scarce, yet existing relicts of intrusive contacts of granitic precursor of the Śnieżnik orthogneisses locally emplaced in the Gierałtów migmatitic gneisses (Figs. 2A, B and 4C, details in Redlińska-Marczyńska and Żelaźniewicz, 2011) provide the key geological evidence of the relationships between the gneisses in the Orlica-Śnieżnik Dome. Unfortunately, it may pass unnoticed because of obliterations by later processes. Our structural observations summarized in a model blockdiagram (Fig. 15) easily explain why gneisses of both the formations carry significantly different structural records. They also explain why the Śnieżnik orthogneisses were less deformed and became metamorphosed at P-T conditions lower than those estimated for the Gierałtów gneisses. Eventually, our model observes the rule that granitic melts tend to acquire less diversified aspects, lithological, petrographic, isotopic, and structural or else, than the source rocks.

In a more general view, all the above-mentioned phenomena were likely driven by heat from an upwelling mantle wedge and decompression in the back-arc environment. Having considered also the isotopic ages determined for metarhyolites set in the Młynowiec-Stronie Group (Murtezi, 2006; Jastrzębski et al., 2010, 2015; Mazur et al., 2013), one may assume that this regime was active at least at $\sim 515-475 \mathrm{Ma}$. Crustal thickening due to the Variscan collision brought about the vertical flattening and resulted in regional metamorphism under amphibolite facies conditions that climaxed at $\sim 340 \mathrm{Ma}$, as demonstrated by practically all published isotopic studies. We suggest that the OSD gneisses variously responded to those conditions, especially the earlier migmatised and equilibrated Gierałtów gneisses.

\section{CONCLUSIONS}

The most important conclusions of this study are as follows:

1. In the Międzygórze Antiform, earlier observations of noticeable differences in derivation and evolution between rocks of the Gieraltów and Śnieżnik gneiss formations have been further confirmed.

2. Among protoliths of the varied Gieraltów rocks are paragneisses, while the compositionally less heterogeneous Śnieżnik rocks are exclusively orthogneisses and their granitic protolith intruded the former and similar rocks at $\sim 500 \mathrm{Ma}$.

3. Early deformation and metamorphism $>$ migmatisation in the Gierałtów rocks occurred slightly prior to and coevally with the intrusion at $\sim 515-475 \mathrm{Ma}$; the Śnieżnik rocks have shorter and less complex structural history. 
4. In the folded migmatitic Gierałtów rocks, more or less zoned outgrowths, aged $\sim 500 \mathrm{Ma}$, developed on older zircon xenocrysts, the zonation being furnished by fluids relating to partial melting.

5. Both gneiss formations then underwent jointly a tectonometamorphic episode at $\sim 340 \mathrm{Ma}$, to which their responses differed to some extent, being controlled by early and later acquired differences.

6. The $\sim 340$ Ma event was assisted by Zr-carrying and significantly U-enriched fluids. Their operation was much impeded in the multiply folded, fine-grained migmatitic Gierałtów gneisses that possessed two foliation sets. In contrast, it was significantly enhanced in the coarse-grained augen Śnieżnik gneisses, which acquired then a constrictional L-type fabric in the hinge zones of large-scale folds, and in the accompanying shear zones. Therefore, in the Gierałtów rocks, none or at most very poor U-rich zircon rims developed on the $\geq 500 \mathrm{Ma}$ zircon grains, whilst in the Śnieżnik rocks the $\geq 500 \mathrm{Ma}$ zircon grains acquired quite extensive, more or less zoned outgrowths.

Acknowledgements. This study was financially supported by the State Committee for Scientific Research, Poland (grant No. 3P04D 06224 and grant No. 2P04D 018 30). We are grateful to T. Oberc-Dziedzic, J. Žak and an anonymous reviewer who are acknowledged for constructive remarks. L. Krzemiński and T. Peryt are thanked for careful editorial handling.

\section{REFERENCES}

Aleksandrowski, P., Mazur, S., 2002. Collage tectonics in the northeasternmost part of the Variscan Belt: the Sudetes, Bohemian Massif. Geological Society Special Publications, 201: 237-277.

Aleksandrowski, P., Kryza, R., Mazur, S., Pin, C., Zalasiewicz, J.A., 2000. The Polish Sudetes: Caledonian or Variscan? Transactions of the Royal Society of Edinburgh: Earth Sciences, $\mathbf{9 0}$ 127-146.

Anczkiewicz, R., Szczepański, J., Mazur, S., Storey, C., Crowley, Q., Villa, I.M., Thirlwall, M.F., Jeffries, T.E., 2007. Lu-Hf geochronology and trace element distribution in garnet: Implications for uplift and exhumation of ultra-high pressure granulites in the Sudetes, SW Poland. Lithos, 95: 363-80.

Borkowska, M., 1994. Gnejsy metamorfiku Śnieżnika w Sudetach w świetle badań mineralogiczno-geochemicznych (in Polish). Archiwum Mineralogiczne, 50: 144-145.

Borkowska, M., 1996. P-T conditions of metamorphism in orthogneisses of the Śnieżnik region - Sudetes, Poland. Terra Nostra, 96: 26-30.

Borkowska, M., Choukroune, P., Hameurt, J., Martineau, F., 1990. A geochemical investigation of age, significance and structural evolution of the Caledonian-Variscan granite-gneisses of the Śnieżnik metamorphic area (Central Sudetes, Poland). Geologia Sudetica, 25: 1-27.

Bröcker, M., Klemd, R., 1996. Ultrahigh-pressure metamorphism in the Śnieżnik Mountains (Sudetes, Poland): P-T constraints and geological implications. Journal of Geology, 104: 417-33.

Bröcker, M., Klemd, R., Cosca, M., Brock, W., Larionov, A.N., Rodionov, N., 2009. The timing of eclogite-facies metamorphism and migmatization in the Orlica-Śnieżnik complex, Bohemian Massif: constraints from a geochronological multi-method study. Journal of Metamorphic Geology, 27: 385-403.

Bröcker, M., Klemd, R., Kooijman, E., Berndt, J., Larionov, A., 2010. Zircon geochronology and trace element characteristics of eclogites and granulites from the Orlica-Śnieżnik complex, Bohemian Massif. Geological Magazine, 147: 339-362.

Brueckner, H.K., Medaris, L.G. Jr., Bakun-Czubarow, N., 1991. $\mathrm{Nd}$ and $\mathrm{Sr}$ age and isotope patterns from Variscan eclogites of the eastern Bohemian Massif. Neues Jahrbuch für Mineralogie, Abhandlungen, 163: 169-96.

Budzyń, B., Jastrzębski, M., Kozub-Budzyń, G.A., Konečný, P., 2015. Monazite Th-U-total $\mathrm{Pb}$ geochronology and $\mathrm{P}-\mathrm{T}$ thermodynamic modeling in a revision of the HP-HT metamorphic record in granulites from Stary Gierałtów (NE Orlica-Śnieżnik Dome, SW Poland). Geological Quarterly, 59 (4): 700-717.

Chamberlain, C.P., Lyons, J.B., 1983. Pressure, temperature and metamorphic zonation studies of pelitic schists in the Merrimack Synclinorium, south central New Hampshire. American Mineralogist, 68: 530-540.

Chopin, F., Schulmann, K., Štípská, P., Martelat, J. E., Pitra, P., Lexa, O., Petri, B., 2012a. Microstructural and metamorphic evolution of a high-pressure granitic orthogneiss during conti- nental subduction (Orlica-Śnieżnik dome, Bohemian Massif). Journal of Metamorphic Geology, 30: 347-376.

Chopin, F., Schulmann, K., Skrzypek, E., Lehmann, J., Dujardin, J. R., Martelat, J. E., Lexa, O., Corsini, M., Edel, J.B., Štípská, P., Pitra, P., 2012b. Crustal influx, indentation, ductile thinning and gravity redistribution in a continental wedge: building a Moldanubian mantled gneiss dome with underthrust Saxothuringian material (European Variscan belt). Tectonics, 31, TC1013.

Corfu, F., Hanchar, J.M., Hoskin, P.W.O., Kinny, P. 2003. Atlas of zircon textures. Reviews in Mineralogy and Geochemistry, 53: 469-500.

Cymerman, Z., 1997. Structure, kinematics and an evolution of the Orlica-Śnieżnik Dome, Sudetes. Prace Państwowego Instytutu Geologicznego, 156: 3-120.

Don, J., 1964. The Złote and Krowiarki Mts. as structural elements of the Śnieżnik metamorphic massif (in Polish with English summary). Geologia Sudetica, 1: 79-117.

Don, J., 2001. The relationship between the Gierałtów migmatites and the Śnieżnik granitogneisses within the Kletno fold. Prace Specjalne Polskiego Towarzystwa Mineralogicznego, 19: 189-194.

Don, J., Dumicz, M., Wojciechowska, I., Żelaźniewicz, A., 1990. Lithology and tectonics of the Orlica-Śnieżnik Dome, Sudetes recent state of knowledge. Neues Jahrbuch für Geologie und Paläontologie, Abhandlungen, 197: 159-188.

Don, J., Skácel, J., Gotowała, R., 2003. The boundary zone of the East and West Sudetes on the 1: 50,000 scale geological map of the Velké Vrbno, Staré Město and Śnieżnik Metamorphic Units. Geologia Sudetica, 35: 25-59.

Dumicz, M., 1979. Tectogenesis of the metamorphosed series of the Klodzko District: a tentative explanantion. Geologia Sudetica, 14: 29-46.

Dumicz, M., 1989. The Śnieżnik Mts gneisses sequence in the light of mesostructural analysis of some areas of the Międzygórze and Gierałtów units (in Polish with English summary). Geologia Sudetica, 24: 139-189.

Faryad, S.W., Kachlík, V., 2013. New evidence of blueschist facies rocks and their geotectonic implication for Variscan sutures in the Bohemian Massif. Journal of Metamorphic Geology, 311: 63-82.

Fischer, G., 1936. Der Bau des Glatzer Schneegebirges. Jahrbuch der Preußischen Geologischen Landesanstalt, 56: 712-732.

Franke, W., Żelaźniewicz, A., Porębski, S.J., Wajsprych, B., 1993. Saxothuringian zone in Germany and Poland: differences and common features. Geologische Rundschau, 82: 583-599.

Gebauer, D., Schertl, H.-P., Brix, M., Schreyer, W., 1997. 35 Ma old ultrahigh-pressure metamorphism and evidence for very rapid exhumation in the Dora Maira Massif, Western Alps. Lithos, 41: 5-24. 
Geisler, T., Schaltegger, U., Tomaschek, F., 2007. Re-equlibration of zircons in aqueous fluids and melts. Elements, 3: 43-50.

Glascock, J., Schneider, D.A., Manecki, M., 2003.Exhumation history of the Orlica-Snieznik Dome (Bohemian Massif) revealed through Ar-Ar thermochronometry. GSA, Abstracts, 35: 638.

Gordon, S.M., Schneider, D.A., Manecki, M., Holm, D.K., 2005. Exhumation and metamorphism of an ultrahigh-grade terrane: geochronometric investigations of the Sudety Mountains (Bohemia), Poland and Czech Republic. Journal of the Geological Society, 162: 841-855.

Grześkowiak, A., 2004. Genesis of diversification of the Międzygórze Structure Gneisses, Śnieżnik Metamorphic Unit. Ph.D. thesis, Archive of the Institute of Geology, Adam Mickiewicz University, Poznań, Poland.

Grześkowiak, A., Żelaźniewicz, A., 2002. On the significance of gneissic enclaves in the $500 \mathrm{Ma}$ metagranite, the Lądek-Śnieżnik Metamorphic Unit, the West Sudetes. GeoLines, 14: 28-29.

Grześkowiak, A., Żelaźniewicz, A., Fanning, C.M., 2005. Early Palaeozoic syntectonic migmatization preceded Variscan metamorphism in the Orlica-Śnieżnik Dome, Sudetes: U-Pb SHRIMP Evidence. GeoLines, 19: 46-48.

Gunia, T., 1974. Microflore of Pre-Cambrian limestones of the Duszniki Zdrój Region (The Central Sudeten) (in Polish with English summary). Annales Societatis Geologorum Poloniae, 44: 65-91.

Gunia, T., Wierzchołowski, B., 1979. Problematical microfossils in the paragneiss of the Bystrzyckie Mts (Sudetes, Poland) (in Polish with English summary). Geologia Sudetica, 14: 8-25.

Hoskin, P.W.O., Black, L.P., 2000. Metamorphic zircon formation by solid-state recrystallization of protolith igneous zircon. Journal of Metamorphic Geology, 18: 423-439.

Hoskin, P.W.O., Schaltegger, U., 2003. The composition of zircon and igneous and metamorphic petrogenesis. Reviews in Mineralogy and Geochemistry, 53: 27-62.

Jastrzębski, M., 2005. The tectonometamorphic evolution of the marbles in the Lądek-Śnieżnik Metamorphic Unit, West Sudetes. Geologia Sudetica, 37: 1-26.

Jastrzebski, M., 2009. A Variscan continental collision of the West Sudetes and the Brunovistulian terrane: a contribution from structural and metamorphic record of the Stronie Formation, the Orlica-Śnieżnik Dome, SW Poland. International Journal of Earth Sciences (Geologische Rundschau), 98: 1901-1923.

Jastrzębski, M., Żelaźniewicz, A., Nowak, I., Murtezi, M., Larionov, A., 2010. Protolith age and provenance of metasedimentary rocks in Variscan allochthon units: U-Pb SHRIMP zircon data from the Orlica-Śnieżnik Dome, West Sudetes. Geological Magazine, 147: 416-433.

Jastrzębski, M., Budzyń, B., Stawikowski, W., 2015. Structural, metamorphic and geochronological record in the Goszów quartzites of the Orlica-Śnieżnik Dome (SW Poland): implications for the polyphase Variscan tectonometamorphism of the Saxothuringian terrane. Geological Journal, doi: 10.1002/gj.2647

Klemd, R., Bröcker, M., 1999. Fluid influence on mineral reactions in ultrahigh-pressure granulites: a case study in the Śnieżnik Mts. (West Sudetes, Poland). Contributions to Mineralogy and Petrology, 136: 358-73.

Klemd, R., Bröcker, M., Schramm, J., 1995. Characterization of amphibolite-facies fluids of Variscan eclogites from the OrlicaŚnieżnik dome (Sudetes, SW Poland). Chemical Geology, 119 101-113.

Kröner A., Štípská, P., Schulmann, K., Jaeckel, P., 2000. Chronological constraints on the pre-Variscan evolution of the northeastern margin of the Bohemian Massif, Czech Republic. Geological Society Special Publications, 179: 175-198.

Lackey, J.S., Valley, J.W., Hinke, H.J., 2006. Deciphering the source and contamination history of peraluminous magmas using ${ }^{18} \mathrm{O}$ of accessory minerals: examples from garnet-bearing plutons of the Sierra Nevada batholiths. Contributions to Mineralogy and Petrology, 151: 20-44.

Lange, U., Bröcker, M., Mezger, K., Don, J., 2002. Geochemistry and $\mathrm{Rb}-\mathrm{Sr}$ geochronology of a ductile shear zone in the Orlica-Śnieżnik dome (West Sudetes, Poland). International Journal of Earth Sciences, 91: 1005-1016.
Lange, U., Bröcker, M., Armstrong, R., Żelaźniewicz, A., Trapp, E., Mezger, K., 2005. The orthogneisses of the Orlica-Śnieżnik complex (West Sudetes, Poland): geochemical characteristics, the importance of pre-Variscan migmatization and constraints on the cooling history. Journal of the Geological Society, 162: 973-984.

Lucassen, F., Franz, G., Rhede, D., Wirth, R., 2010. Ti-Al zoning of experimentally grown titanite in the system $\mathrm{CaO}-\mathrm{Al}_{2} \mathrm{O}_{3-}$ $\mathrm{TiO}_{2}-\mathrm{SiO}_{2}-\mathrm{NaCl}-\mathrm{H}_{2} \mathrm{O}-(\mathrm{F})$ : evidence for small-scale fluid heterogeneity. American Mineralogist, 95: 1365-1378.

Ludwig, K. R., 2001. SQUID 1.02, A User Manual, A Geochronological Toolkit for Microsoft Excel. Berkeley Geochronology Center Special Publication, 2.

Ludwig, K.R., 2003. Isoplot/EX version 3.0, A Geochronological Toolkit for Microsoft Excel. Berkeley Geochronology Center Special Publication, 4.

Maluski, H., Rajlich, P., Soucek, J., 1995. Pre-Variscan, Variscan and Early Alpine thermo-tectonic history of the north-eastern Bohemian Massif: an ${ }^{40} \mathrm{Ar} /{ }^{39} \mathrm{Ar}$ study. Geologische Rundschau, 84: 345-358.

Marheine, D., Kachlík, V., Maluski, H., Patočka, F., Żelaniewicz, A., 2002. The ${ }^{40} \mathrm{Ar} /{ }^{39} \mathrm{Ar}$ ages from the West Sudetes (NE Bohemian Massif): constraints on the Variscan polyphase tectonothermal development. Geological Society Special Publications, 201: 133-155.

Markl, G., Piazolo, S., 2004. Stability of high-Al titanite from low-pressure calcsilicates in light of fluid and host-rock composition. American Mineralogist, 84: 37-47.

Mazur, S., Szczepański, J., Turniak, K., McNaughton, N., 2012 Location of the Rheic suture in the eastern Bohemian Massif: evidence from detrital zircon data. Terra Nova, 24: 199-206.

Mazur, S., Turniak, K., Szczepański, J., McNaughton, N.J., 2013. Vestiges of Saxothuringian crust in the Central Sudetes, Bohemian Massif: Zircon evidence of a recycled subducted slab provenance. Gondwana Research, 27: 825-839.

Miller, C.F., Stoddard, E.F., 1978. Origin of garnet in granitic rocks: an example of the role of $\mathrm{Mn}$ from the Old Woman-Piute range, California. Geological Association of Canada/Mineral Association of Canada, Abstract Programs, 3: 456.

Miller, C.F., Stoddard, E.F., 1981. The role of manganese in the paragenesis of magmatic garnet: an example from the Old Woman-Piute Range, California. Journal of Geology, 89: 233-246.

Murtezi, M., 2006. The acid metavolcanic rocks of the Orlica-Śnieżnik Dome (Sudetes): their origin and tectono-metamorphic evolution. Geologia Sudetica, 38: 1-38.

Nemchin, A.A., Pidgeon, R.T., 1997. Evolution of the Darling Range Batholith, Yilgarn Craton, Western Australia: a SHRIMP zircon study. Journal of Petrology, 38: 625-649.

Oliver, G.J.H., Corfu, F., Krogh, T.E., 1993. U-Pb ages from SW Poland: evidence for a Caledonian suture zone between Baltica and Gondwana. Journal of the Geological Society, 150: 355-369.

Owen, J.V., Marr, R.A., 1999. Contrasting garnet parageneses in a composite Grenvillian granitoid pluton. Newfoundland Mineralogical Magazine, 54: 367-380.

Paces, J. B., Miller, J. D., 1993. Precise U-Pb ages of Duluth Complex and related mafic intrusions, northeastern Minnesota: geochronological insights to physical, petrogenetic, paleomagnetic, and tectonomagmatic process associated with the $1.1 \mathrm{Ga}$ Midcontinent Rift System. Journal of Geophysical Research, 98: 13997-14013

Peřestý, V., Lexa, O., Jeřábek, P., Racek, M., 2015. Early Variscan (and pre-Variscan) evolution of the western part of the Teplá-Barrandian Unit. CETeG 2015 Field Guide, Czech Geological Survey: 1-30.

Pidgeon, R.T., Compston, W., 1992. A SHRIMP ion microprobe study of inherited and magmatic zircons from four Scottish Caledonian granites. Transactions of the Royal Society of Edinburgh: Earth Sciences, 83: 473-483.

Pin, C., Kryza, R., Oberc-Dziedzic, T., Mazur, S., Turniak, K., Waldhausrová, J., 2007. The diversity and geodynamic significance of Late Cambrian (ca. $500 \mathrm{Ma}$ ) felsic anorogenic magmatism in the northern part of the Bohemian Massif: a re- 
view based on $\mathrm{Sm}-\mathrm{Nd}$ isotope and geochemical data. GSA Special Paper, 423: 209-229.

Plank, T., 1987. Magmatic garnets form the Cardigan pluton and the Acadian thermal event in southwest New Hampshire. American Mineralogist, 72: 681-688.

Pressler, R.E., Schneider, D.A., Petronis, M.S., Holm, D.K., Geissman, J.W., 2007. Pervasive horizontal fabric and rapid vertical extrusion: Lateral overturning and margin sub-parallel flow of deep crustal migmatites, northeastern Bohemian Massif. Tectonophysics, 443: 19-36.

Přikryl, R., Schulmann, K., Melka, R., 1996. Perpendicular fabrics in the Orlické hory orthogneisses (western part of the Orlice-Sněžník dome, Bohemian massif) due to high temperature E-W deformational event and late lower temperature N-S overprint. Journal of the Czech Geological Society, 41: 156-166.

Redlińska-Marczyńska, A., 2011. Gierałtów versus Śnieżnik gneisses - what is the real difference? Geologos, 17: 71-96.

Redlińska-Marczyńska, A., Żelaźniewicz, A., 2011. Gneisses in the Orlica-Śnieżnik Dome, West Sudetes: a single batholitic protolith or a more complex origin? Acta Geologica Polonica, 61: 307-339.

Sawicki, L. 1995. Geological map of Lower Silesia with adjacent Czech and German territories 1:100 000. Polish Geological Institute, Warszawa.

Schaltegger, U., Fanning, C.M., Gunther, D., Maurin, J.C., Schulmann, K., Gebauer, D., 1999. Growth, annealing and recrystallization of zircon and preservation of monazite in high-grade metamorphism: conventional and in situ $\mathrm{U}-\mathrm{Pb}$ isotope, cathodoluminescence and microchemical evidence. Contribution to Mineralogy and Petrology, 134: 186-201.

Schneider, D.A., Zahniser, S.J., Clascock, J.M., Gordon, S.M., Manecki, M., 2006. Thermochronology of the West Sudetes (Bohemian Massif): rapid and repeated eduction in the eastern Variscides, Poland and Czech Republic. American Journal of Science, 306: 846-873.

Schulmann, K., Lexa, O., Štípská, P., Racek, M., Tajčmanová, L., Konopásek, J., Edel, J.-B., Peschler, A., Lehmann, J., 2008. Vertical extrusion and horizontal spreading of orogenic lower crust: a key exhumation mechanism in large hot orogens? Journal of Metamorphic Geology, 26: 273-297.

Skrzypek, E., Schulmann, K., Štípská, P., Chopin, F., Lehmann, J., Lexa, O., Haloda, J., 2011. Tectono-metamorphic history recorded in garnet porphyroblasts: insights from thermodynamic modelling and electron backscatter diffraction analysis of inclusion trails. Journal of Metamorphic Petrology, 29: 473-496.

Skrzypek, E., Lehmann, J., Szczepański, J., Anczkiewicz, R., Štípská, P., Schulmann, K., Kröner, A., Białek, D., 2014. Time-scale of deformation and intertectonic phases revealed by P-T-D-t relationships in the orogenic middle crust of the Orlica-Śnieżnik Dome, Polish/Czech Central Sudetes. Journal of Metamorphic Geology, 32: 981-1003.

Smulikowski, K., 1973. Le roches metamorphiques du Mont Śnieżnik et la region de Lądek. Revue des problemes geologiques des zones profondes de l'ecorce terrestre en Basse Silesie: 77-102. Wyd. Geol., Warszawa.

Smulikowski, K., 1976. Ultramafic rocks from the vicinity of Złoty Stok (Lower Silesia). Bulletin de l'Academie Polonaise des Sciences, Série de les Sciences de la Terre, Warszawa, 24: 244-251.

Song, Y., Xu, H., Zhang, J., Wang, D., Liu, E., 2014. Syn-exhumation partial melting and melt segregation in the Sulu UHP terrane: Evidences from leucosome and pegmatitic vein of migmatite. Lithos, 202-203: 55-75.

Spear, F.S., 1993. Metamorphic Phase Equilibria and Pressure-Temperature-Time Paths. Mineralogical Society of America, Washington, D. C.

Stawikowski, W., 2006. The problem of garnet composition in eclogite-bearing gneisses from the Śnieżnik Metamorphic Unit. GeoLines, 20: 122.

Štípská, P., Schulmann, K., Kröner, A., 2004. Vertical extrusion and middle crustal spreading of omphacite granulite: a model of syn-convergent exhumation (Bohemian Massif, Czech Republic). Journal of Metamorphic Geology, 22: 179-98.
Štípská, P.,Chopin, F., Skrzypek, E., Schulmann, K., Pitra, P., Lexa, O., Martelat, J.E., Bolinger, C., Žáčková, E., 2012. The juxtaposition of eclogite and mid-crustal rocks in the Orlica-Śnieżnik Dome, Bohemian Massif. Journal of Metamorphic Geology, 30: 213-234.

Suess, F.E., 1912. Die moravischen Fenster und ihre Beziehung zum Grundgebirge der Hohen Gesenke. Denkschriften der Österreichischen Akademie der Wissenschaften, MathematikNatur, 88: 541-631.

Teisseyre, H., 1957. Budowa geologiczna okolic Międzygórza (in Polish). In: Przewodnik do XXX Zjazdu Polskiego Towarzystwa Geologicznego w Ziemi Kłodzkiej (ed. H. Teisseyre): 54-72.

Teisseyre, H., 1973. Geology of the Śnieżnik Mountain Group. In: Revue des problèmes géologiques des zones profondes de l'écorce terrestre en Basse Silésie (ed. K. Smulikowski): 59-73. Wyd. Geol., Warszawa.

Tera, F., Wasserburg, G.J., 1972. U-Th-Pb systematics in three Apollo 14 basalts and the problem of initial $\mathrm{Pb}$ in lunar rocks. Earth and Planetary Science Letters, 14: 281-304.

Turniak, K., Mazur, S., Wysoczański, R., 2000. SHRIMP zircon geochronology and geochemistry of the Orlica-Śnieżnik gneisses (Variscan belt of Central Europe) and their tectonic implications. Geodinamica Acta, 13: 293-312.

Van Breemen, O., Aftalion, M., Bowes, D.R., Dudek, A., Misař, Z., Povondra, P., Vraná, S.,1982. Geochronological studies of the Bohemian Massif, Czechoslovakia, and their significance in the evolution of Central Europe. Transactions of the Royal Society of Edinburgh, Earth Sciences, 73: 89-108.

Vavra, G., 1994. Systematics of internal zircon morphology in major Variscan granitoid types. Contributions to Mineralogy and Petrology, 117: 331-344.

Williams, I., 1998. U-Th-Pb geochronology by ion microprobe. Reviews in Economic Geology, 7: 1-35.

Williams, I.S., Hergt, J.M., 2000. U-Pb dating of Tasmanian dolerites: a cautionary tale of SHRIMP analysis of high-U zircon. In: Beyond 2000: New frontiers in Isotope Geoscience, Lorne, Abstracts and Proceedings (eds. J.D. Woodhead, J.M. Hergt and W.P. Noble): $185-188$.

Żelaźniewicz, A., 1984. Synmetamorphic penetrative mylonitization in orthogneisses of the Bystrzyca Mts, Sudetes. Acta Geologica Polonica, 34: 111-130.

Żelaźniewicz, A., 1988. Orthogneisses due to irrotational extension, a case from the Sudetes, NE Bohemian Massif. Geologische Rundschau, 77: 671-682.

Żelaźniewicz, A., 1991. Uwagi o deformacji ortognejsów oczkowych w kopule orlicko-śnieżnickiej (in Polish). In: Następstwo serii skalnych masywu Śnieżnika w świetle kartografii geologicznej, analizy strukturalnej i badań radiometrycznych. Konferencja terenowa Lądek Zdrój 18-19 października 1991: 122-136. Wrocław.

Żelaźniewicz, A., Bakun-Czubarow, N., 2002. A polyphase exhumation of the ultra-high $P$ eclogites from Nowa Wieś in the Międzygórze unit, the Sudetes. GeoLines, 14: 107-108.

Żelaźniewicz, A., Mazur, S., Szczepański, J. 2002. The Lądek-Śnieżnik Metamorphic Unit - recent state of knowledge. GeoLines, 14: 115-125.

Żelaźniewicz, A., Nowak, I., Larionov, A.N., Presnyakov, S., 2006. Syntectonic lower Ordovician migmatite and post-tectonic Upper Visean syenite in the western limb of the Orlica-Śnieżnik Dome, West Sudetes: U-Pb SHRIMP data from zircons. Geologia Sudetica, 38: 63-80.

Żelaźniewicz, A., Kromuszczyńska, O., Biegała, N., 2013. Quartz C-axis fabrics in constrictionally strained orthogneisses: implications for the evolution of the Orlica-Śnieżnik Dome, the Sudetes, Poland. Acta Geologica Polonica, 63: 697-722.

Żelaźniewicz, A., Budzyń, B., Ilnicki, S., Jastrzębski, M., Murtezi, M., Redlińska-Marczyńska, A., Stawikowski, W., Szczepański, J., 2014a. The CETeG 2014 excursion to crystalline basement of the Orlica-Śnieżnik Dome, the Sudetes. Geologia Sudetica, 42: 125-136.

Żelaźniewicz, A., Jastrzębski, M., Redlińska-Marczyńska, A., Szczepański, J., 2014b. The Orlica-Śnieżnik Dome, the Sudetes, in 2002 and 12 years later. Geologia Sudetica, 42: 105-123. 